\title{
MAMMALS OF BANKA, MENDANAU, AND BILLITON ISLANDS, BETWEEN SUMATRA AND BORNEO.
}

\author{
By Marcus Ward Lyon, Jr., \\ Assistant Curatar, Division of Mammals.
}

This paper is based on 274 specimens of mammals collected on the islands of Banka and Billiton and on the little island of Mendanau lying off the west coast of Billiton (see map, page 577), by Dr. W. L. Abbott, between January 20, 1904, and August 14, 1904, and pre sented to the United States National Museum. No general account, so far as I am aware, has appeared concerning the mammal fauna of Banka. Jentink ${ }^{a}$ has twice published lists of the mammals of Billiton. Many specimens in the collection of the Leyden Museum are recorded from Banka by Schlegel, by Jentink, ${ }^{b}$ and by Müller. ${ }^{c}$

Recently Willink ${ }^{d}$. has published a list of the mammals of the Dutch East Indies, showing the species known from Banka and Billiton as well as from many other islands.

Banka, also spelled Bangka, the larger of the two islands, is just off the coast of Sumatra from which it is separated by a channel less than 10 miles wide in places and varying in depth between 10 and 19 fathoms. The average width of the island is about 50 miles and its length, which extends from northwest to southeast, is about 150 miles. There are several hills on it, the highest of which is in the northern part and is recorded as being 2,296 feet in altitude. Doctor Abbott's remarks on his collecting stations are given beyond.

Billiton, measuring about 50 miles square, lies nearly 50 miles to the east of the southern extremity of Banka. The highest hill on it is said to be 1,673 feet in altitude. The waters between Ranka and Billiton have a depth ranging from 19 to 29 fathoms. A number of small islands occupy this channel. Doctor Abbott collected only on one of them, Mendanau, about 4 miles to the west of Billiton. Billi-

a Notes, Leyden Museum, XII, 1890, pp. 149-154; and XIII, 1891, pp. 207-209.

${ }^{b}$ Catalogue Systematique des Mammifères. Catalogue Osteologique des Mammifères, and Simiae. Mus. d'Hist. Nat. Pays-Bas.

${ }^{c}$ Verhandl. Natuur. Geschied. Nederl. Over. Bezitt. Zool., 1839-44.

${ }^{d}$ Natuurkundig Tijdschrift Nederlandsch-Indië, XLV, 10th ser., Pt. 9, pp. 153-345. 
ton is separated from the west coast of Borneo by the wide Karimata Strait (about 125 miles), which has an average depth of about 25 fathoms. The notes on Doctor Abbott's collecting stations are given beyond.

From the geographical situation of these two islands it would be expected that their mammal faunas would be similar to the fauna of Sumatra; but from a study of Doctor Abbott's collections it becomes apparent that the zoological relations of these two islands, so far as mammals are concerned, are with distant Borneo, and not with near by Sumatra. The relationship between themselves is rather close.

\section{SYSTEMATIC LIST OF SPECIES.}

TRAGULUS BANCANUS, new species.

1887. Tragulus napu Jentink, Mus. d'Hist. Nat. de Pays-Bas, IX, Cat. Osteol. Mammifères, 1887, p. 156.

1891. Tragulus napu Jextink, Notes Leyden Museum, XIII, 1891, p. 209.

1905. Tragulus napu Willink, Natuurkundig Tijdschrift Nederlandsch-Indië, XLV, p. 198.

Type--Adult female, skin and skull, Cat. No. 124714, U.S.N.M. Collected at Tanjong Tedong, island of Banka, east of Sumatra, May 31, 1904, by Dr. W. L. Abbott. Original number 3283.

Diagnostic characters. - Very closely related to Tragulus napu of Sumatra, but brighter in color; skull not quite so large.

Color.-Type: General color above tawny-ochraceous (in T. napu it is ochraceous), but everywhere very largely -obscured by the conspicuous black tips to the hairs. On the sides the tawny-ochraceous is replaced by a dull ochraceous or ochraceous buff. Top and sides of the head and neck similar in color to back, but less obscured by black tips to the hairs, except along the indistinct nape stripe. Underparts white, except a short narrow suffusion of the color of the sides just posterior to the chest. Throat pattern normal, the hairs of the dark stripes a dull tawny-ochraceous, but heavily tipped with black so that but little of the former color is seen. Hairs of collar dull ochraceous tipped with black, both colors equally prominent. Forearm similar in color to the back on outer side, but black tips to hairs less conspicuous and scarcely noticeable or absent about the wrist. Inner side of foreleg white. Hind legs similar in color to the sides, but black less conspicuous. Just above heel, at situation of gland, a rather conspicuous spot of tawny-ochraceous, in contrast to the general ochraceous color of the legs. Tail like back above, but black not so conspicuous; white below and at tip.

Skull and teeth. - There are no characters by which the skull of Tragulus bancanus can be distinguished from that of $T$. napu.

Measurements. - See table, page 581. 
Specimens examined.-Five females and 1 male, all from the island of Banka, as follows: Klabat Bay, 3; Tanjong Bedaan, 1; Tanjong Tedong, 1; Tanjong Rengsam, 1.

Remarks. - The series of Tragulus bancanus is very uniform in color. Two of the specimens have the black tips of the hairs worn off, and are consequently lighter than the others. It is most closely related to T. napu, from which it differs in its brighter color. It differs in the same respect from $T$. canescens of the Malay Peninsula, as well as in its slightly smaller size.

\section{TRAGULUS BILLITONUS, new species.}

1891. Tragulus napu, melanistic variety, Jentink, Notes Leyden Museum, XIII, 1891, p. 209.

1905. Tragulus nари WiLlink, Natuurkundig Tijdschrift Nederlandsch-Indië, XLV, p. 198.

Type.-Adult male, skin and skull, Cat. No. 124929, U.S.N.M., collected at Tanjong Batu, Billiton Island, east of Sumatra, July 20, 1904, by Dr. W. L. Abbott. Original number 3524.

Diagnostic characters.-A member of the Tragulus napu group, related to T. pretiellus and T. umbrinus, but darker and duller in color than the former, lacking the bright color along the sides of the body, neck, and head, and not quite so dark as the latter, and with a welldefined nape stripe instead of the diffused dark color of the neck in umbrinus.

Color.-Type: General color of hairs above tawny-ochraceous, but heavily tipped with black, the latter color predominating in the general effect. On the sides the tawny-ochraceous is replaced by buff and the black tips to the hairs are less conspicuous. Top and sides of head and neck similar in color to the back, but black tips to the hair's less conspicuous except along the rather narrow nape stripe. Under parts white in region of chest and groin, but the middle of the belly, for an extent of $150 \mathrm{~mm}$., is suffused with ochraceous buff. Throat pattern normal, the hairs a somewhat duller tawny-ochraceous than the back and heavily tipped with black so that the latter color predominates. Hairs of collar lighter in color, approaching ochraceous buff, with black tips, both colors equally prominent. Foreleg generally tawnyochraceous, without much admixture of black. A narrow, white line extends on the inner side of the leg from the wrist upward to meet the white of the chest. Hind leg similar to foreleg in color, but generally darker and with more white on the inner side. Upper surface of tail similar to back, but black of hairs not so conspicuous. Tip and underside of tail white. Ears, orbital ring, preorbital stripe, nose and lips blackish.

Skull and teeth.-Apparently there are no characters by which to distinguish the skull of Tragulus billitonus from that of related species. 
Measurements. - See page 581.

Specimens examined.- Eight males, two females, all from the island of Billiton; Tanjong Batu, six; Bukit Menguru, three; Tanjong Poetak, one.

Remarks.-The series is fairly uniform in color. The underparts are mainly whitish in most of the specimens; the type has the most extensive suffusion. Many of the specimens have a narrow, dark line extending in the median line of the chest, sometimes from the collar to the middle of the belly, but usually shorter. Two of the specimens, Cat. Nos. 124930 and 125003, U.S.N.M., are somewhat lighter and grayer than the average of the series; Cat. No. 124930, U.S.N.M., is further abnormal or partly albinistic in having a thick scattering of gray hairs on the top of the neck and shoulders and a few scattered whitish patches over the surface of the body.

TRAGULUS LUTEICOLLIS, new species.

1891. Tragulus kanchil Jentink, Notes Leyden Museum, XIII, 1891, p. 209.

Type.-Adult male, skin and skull, Cat. No. 124733, U.S.N.M., collected at Tanjong Bedaan, island of Banka, east of Sumatra, June 12, 1904, by Dr. W. L. Abbott. Original number 3311.

Diagnostic characters. - Very closely related to Tragulus kanchil of Sumatra, from which it differs in a generally duller color very noticeable on side of head and neck, and less black on the upper parts. It is slightly larger than kanchil, as may be seen by reference to table of measurements on page 581 .

Color--Type: General color of hairs above a dull ochraceous-buff or orange-buff, tipped with black; the two colors about equally prominent except along the well-marked nape stripe and crown of head, which are nearly entirely black. On the sides of the body the black is less in evidence than on the back, and the ochraceous-buff is paler. Underparts generally white, a buffy suffusion in axillæ; a suffused patch, $18 \mathrm{~cm}$. long, of similar color in the ventral line, about $1 \mathrm{~cm}$. wide anteriorly where it is of the same color as the collar and widening out posteriorly to $4 \mathrm{~cm}$. where it is a dull ochraceous-buff unmixed with blackish tips of the hairs. Throat pattern normal, similar in color to the middle of the sides; less black in the collar, so that it is nearly a clear dull ochraceous-buff. Forelegs almost a pure ochraceous, slightly sprinkled with black in the upper portion. A narrow white stripe on inner side of leg. Hind leg generally similar to color of middle of sides, but a little brighter; inner side white. Upper surface of the tail like back; tip and underside white. Sides of head and neck a dull orange or ochraceous-buff, more buffy anteriorly, grizzled by the blackish tips to the hairs. Ear's blackish.

Five of the specimens of Tragulus luteicollis are considerably lighter in color along the back and sides than is the type specimen and rest of 
the series, due to the wearing off of the black tips to the hairs. The general ochraceous buff is also lighter and duller in color in these specimens.

Skull and teeth.- There are no characters by which the skull of Tragulus luteicollis can be distinguished from that of T. kanchil. A series of measurements (see table, page 581) shows the skull to be slightly larger in the average.

Measurements.-See table, page 581.

Specimens examined.-Ten females and 8 males; 11 fully adult, 3 nearly adult and 4 young; all from the island of Banka; 14 from Tanjong Bedaan, 1 from Tanjong Tedong, 1 from Tanjong Rengsam, and 2 from Parmassan.

Remarks. - Tragulus luteicollis is closely related to T. kanchil, but is readily distinguished by the more yellow color on the sides of the neck, and generally darker back. From $T$. carimatx it differs in the smaller size and more yellow neck. From T. ravus it differs in being generally less ruddy and bright, especially along the sides of the body and neck. 


\begin{tabular}{|c|c|}
\hline  & ఏ \\
\hline 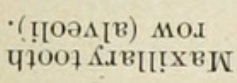 & 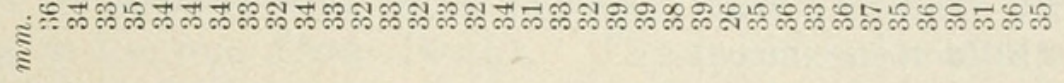 \\
\hline
\end{tabular}

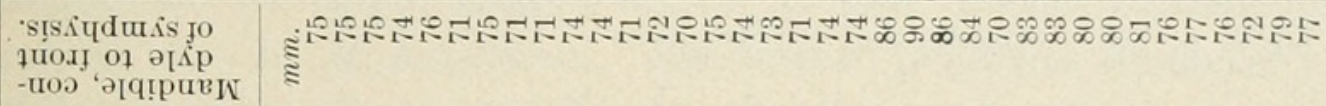

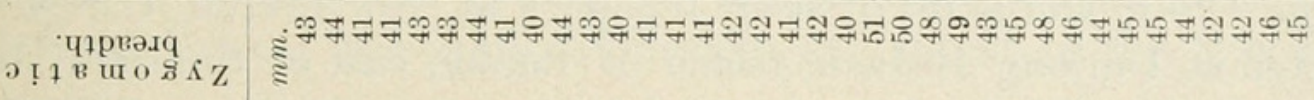
प --оОдวน! 7รвәT ह

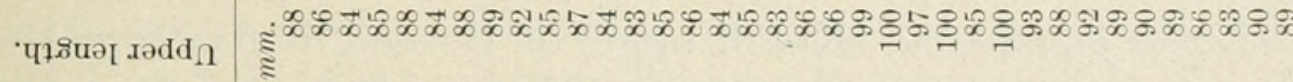

ㄴำนว



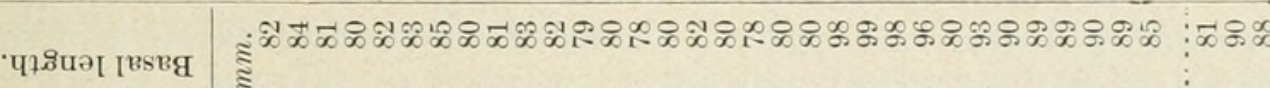

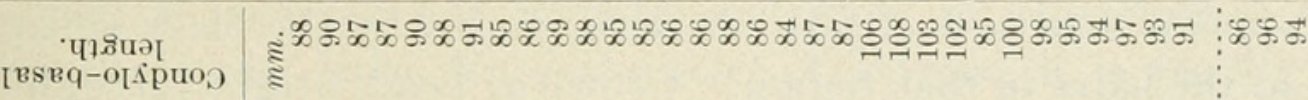



\begin{tabular}{|c|c|}
\hline 'า & 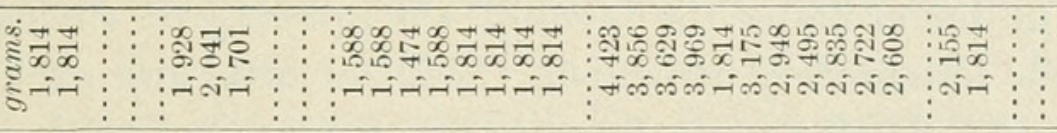 \\
\hline •7о0न рu!н & 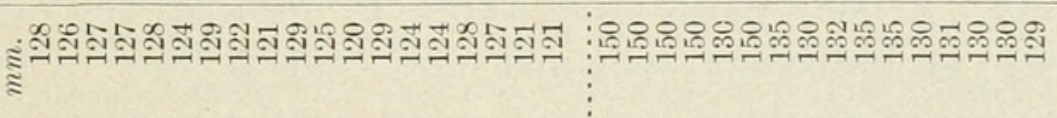 \\
\hline 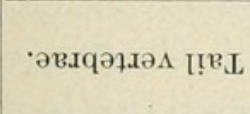 & 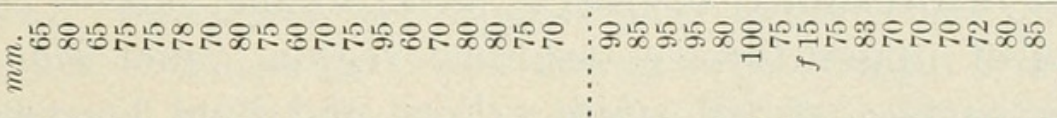 \\
\hline · кроq рив рвән & 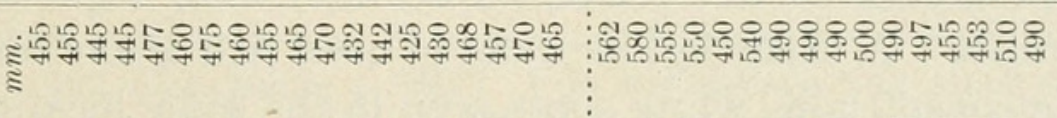 \\
\hline  & 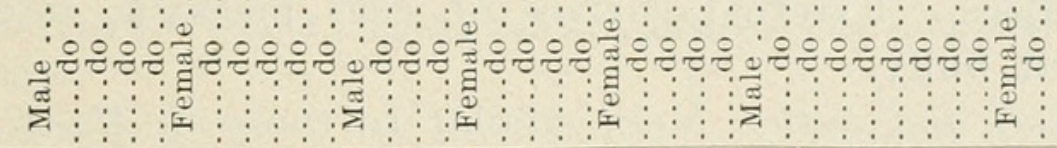 \\
\hline $\begin{array}{l}\dot{\Phi} \\
\stackrel{0}{\Xi} \\
\dot{\Xi}\end{array}$ & 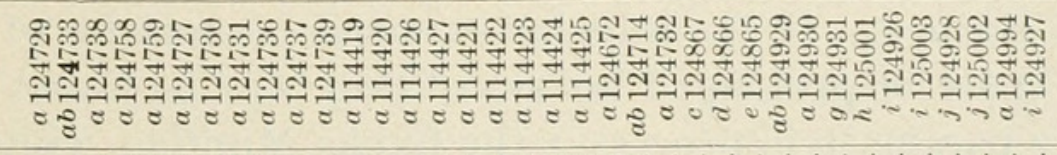 \\
\hline 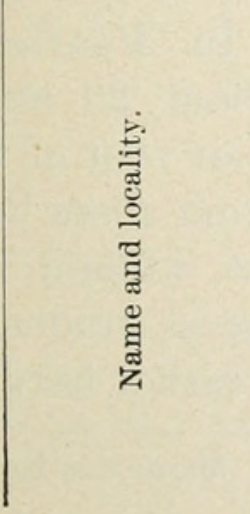 & 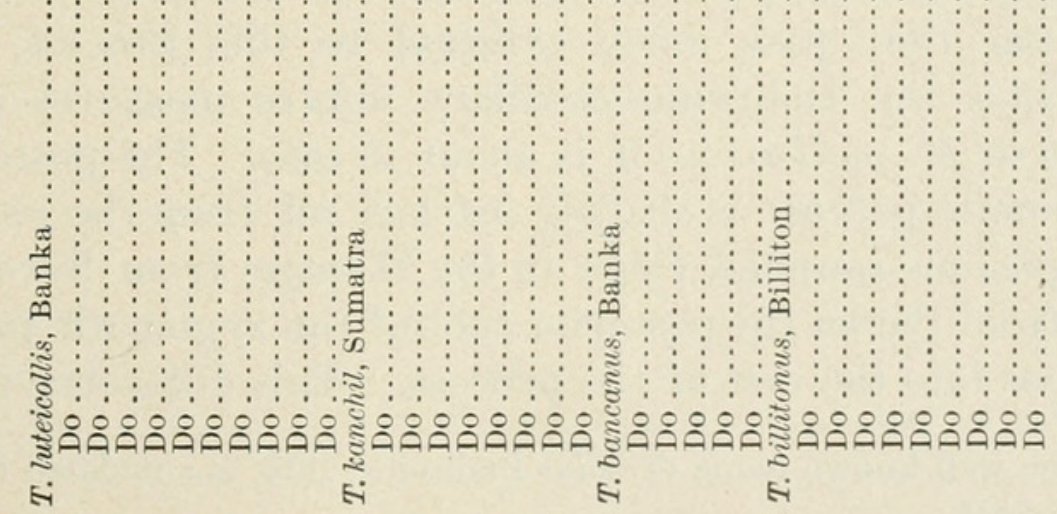 \\
\hline
\end{tabular}


MUNTIACUS $a$ BANCANUS, new species.

1891. Cervulus murtjac Jentink, Notes Leyden Museum, XIII, 1891, p. 209 (Billiton specimens).

1905. Cervulus muntjac Wíllink, Natuurkundig Tijdserhift Nederlandsch-Indië, XLV, p. 189. (Banka and Billiton.)

Type--Skin and skull of adult female, Cat. No. 124726, U.S.N.M., collected at Tanjong Bedaan, island of Banka, east of Sumatra, June 7, 1904, by Dr. W. L. Abbott. Original number 3296.

Diagnostic characters. - Externally similar to Muntiacus moschatus (Blainville) of Sumatra, but decidedly smaller. Skull similar to that of Muntiacus pleiharicus (Kohlbrugge) of Borneo, but interpterygoid space narrower and lachrymo-maxillary suture distinctly longer.

Color.-General color of upper parts of body and tail something between Ridgway's hazel and ferruginous, deepest along the middle line, becoming duller and lighter along the sides and flanks and thighs. Beginning at the ears and extending over the shoulder the ferruginoushazel color is overwashed with blackish, caused by the black subapical rings of the hairs in that region. Crown of head, bright ferruginoushazel. A black line extends from near the base of ear downward and inward to meet the corresponding line of the other side in the middle line at about the level of the opening of the lachrymal gland. Muzzle indefinitely brownish. Sides of head and neck similar to sides of body. Under parts from axillæ to inguinal region similar to sides of body, an indistinct brownish mid-rentral line. Chin, upper throat (lower throat similar to sides of neck), axillæ, narrow band across chest, inside of upper foreleg, inguinal region, inner side of thighs, and under surface of tail white. Fore and hind legs washed with dull brownish. A small lighter colored area just above hoofs corresponds to the conspicuous white spots seen in the same location in the Indian Muntjacs. External surface of ears blackish; internally, scantily haired, buffy.

Skull and teeth.-Very similar to those in Muntiacus pleiharicus from Borneo. If the inferior-external boundaries of the interpterygoid space be prolonged backward they will be found to pass internal to the paramastoid process in the Banka Muntjac, while in the Bornean Muntjac they pass much external to this process. In Muntiacus bancanas the lachrymo-maxillary suture measures about $20 \mathrm{~mm}$., while in $M$. pleiharicus it is about $15 \mathrm{~mm}$. The posterior root of the zygomatic process is sharply marked off from the glenoid fossa by a conspicuous rounded ridge in the Muntjac from Borneo, while in the one from Banka the posterior root of the zygomatic process gradually merges into the rest of the process. This difference is rather hard to

$a$ The well-known name Cervulus Blainville, 1816, is antedated by Muntiacus Rafinesque, 1815. 
describe, but is easily appreciated in viewing the two forms. In the fronto-nasal region and just posteriorly, on the upper surface of the skull, is found a well-marked concavity in the Bornean animal, which is lacking in the one from Banka. The mandibular symphysis measures on its upper aspect about $25 \mathrm{~mm}$. in $M$. pleiharicus and about $20 \mathrm{~mm}$. in $M$. bancanus. The antero-posterior diameter of the first lower premolar is greater in the Bornean animal than in the one from Banka; the same differences are found in the first upper premolars.

Measurements.-For measurements of Banka Muntjacs and specimens from Sumatra, Borneo, and the Malay Peniusula see table, page 584. Specimens examined. - Two adult females, skins and skulls, Cat. No. 124726, U.S. N.M., the ty pe from Tanjong Bedaan, and Cat. No. 124752 , U.S.N.M., from Parmassan, the frontlets and antlers of five males from Parmassan and one frontlet (with skin dried on) and antlers from Buding Kampong, Billiton.

Remarks.-Muntiacus bancanus is at once distinguished by its smaller size from M. moschatus of Sumatra and from 'I'. grandicornis of the Malay Peninsula, from $M$. pleiharicus ${ }^{a}$ of Borneo, it is readily separated by its brighter color, absence of a dorsal stripe, and by welldefined cranial characters. The single specimen from Billiton consisting only of a pair of antlers, the frontlet and its dried skin is very close to the Bankan Muntjac. The colors in the frontlet are bright and well marked, and in size it agrees with the Banka specimens.

$a$ I have referred three specimens of Bornean Muntjacs in the United States National Museum to this species. Two skins of females agree fairly well as to color with the original description of $M$. pleiharicus and possess a dorsal stripe though it is not well marked and the antlers and frontlet of a male are about the same in size as the original figure of $M$. pleiharicus (Kohllorugge, Natuurkundig Tijdschrift voor Nederlandsch 9th ser., IV, 1896, p. 192, plate facing p. 260.) I do not believe that much weight can be placed on the shape of the antlers of $M$. pleiharicus for an adult male from Tenasserin, Cat. No. 111969 U.S.N.M., has antlers and pedicles very similar to those figured by Kohlbrugge. 
Measurements of specimens of Muntjacs from Banka, Borneo, Sumatra, and Malay Peninsula.



$a$ From dried skin.

$b$ Uterus contained a nearly mature embryo. $d$ Last molars not through alveoli. $c$ From mounted skin.

\section{RUSA BROOKEI (Hose).}

Five specimens of a Sambar were obtained by Doctor Abbott on Billiton, which I have referred to this species with some hesitation. A study of the specimens of Malayan Rusa in the National Museum shows that the Sambars from Billiton, Borneo, Pagi Island, and Nias Island are distinctly smaller than specimens of Rusa equina from the Malay Peninsula. (See table of measurements, page 585.) It is possible that they may represent more than one form. In Deer of All Lands, Lydekker calls the peninsular and island forms all equina, and on page 153 considers that Hose's brookei is identical with the common Bornean Sambar. It would thus appear that the name brookei should be 
applied to the small form represented by the Bornean animal, and provisionally to the other insular specimens.

No Sambars were obtained on Banka.

Measurements of specimens of Rusa from Malay Peninsula and Archipelago.

\begin{tabular}{|c|c|c|c|c|c|c|c|c|c|}
\hline Locality. & $\begin{array}{l}\text { Num- } \\
\text { ber. }\end{array}$ & Age. & Sex. & 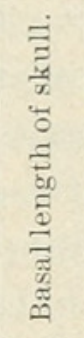 & 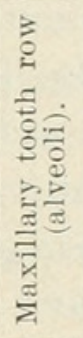 & 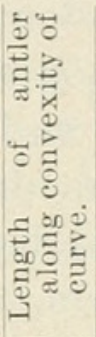 & 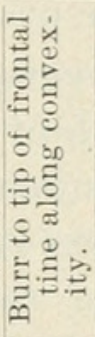 & 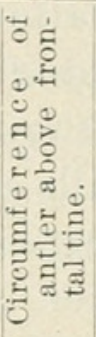 & 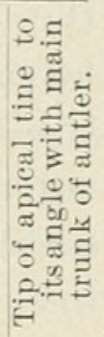 \\
\hline $\begin{array}{l}\text { Malay Peninsula: Victoria } \\
\text { Island. }\end{array}$ & 124004 & Adult. & Male. & $\begin{array}{l}m m . \\
\cdots \cdots\end{array}$ & $\begin{array}{l}m m . \\
\cdots \cdots\end{array}$ & $\begin{array}{r}m m \\
840\end{array}$ & $\begin{array}{r}m m . \\
350\end{array}$ & $\begin{array}{r}m m \\
150\end{array}$ & 2 \\
\hline $\begin{array}{l}\text { Malay Peninsula: Tenas- } \\
\text { serim; Maliwun. }\end{array}$ & 124243 & & a & 350 & 111 & 680 & 400 & 140 & \\
\hline $\begin{array}{l}\text { Do Peninsula: Victoria } \\
\text { Malay } \\
\text { Island. }\end{array}$ & $\begin{array}{l}104091 \\
124005\end{array}$ & $\begin{array}{l}\text { Aged adult } \\
\text { Adult...... }\end{array}$ & & $\begin{array}{l}370 \\
345\end{array}$ & $\begin{array}{l}105 \\
112\end{array}$ & $\begin{array}{l}620 \\
570\end{array}$ & $\begin{array}{r}a 135 \\
300\end{array}$ & $\begin{array}{r}\alpha_{295} \\
122\end{array}$ & \\
\hline $\begin{array}{l}\text { Malay Peninsula: Tenas- } \\
\text { serim; Maliwun. }\end{array}$ & 112172 & Young & d. & 328 & 109 & 470 & 95 & 94 & \\
\hline $\begin{array}{l}\text { Malay Peninsula: Pahang; } \\
\text { Rumpin River. }\end{array}$ & 115382 & Younger & $d$ & 290 & (b) & 110 & (c) & (c) & (c) \\
\hline $\begin{array}{l}\text { Malay Peninsula: Sungei } \\
\text { Balik. }\end{array}$ & 111985 & Adult.. & Female. & 350 & 105 & & & & \\
\hline Billiton: Buding Kampong .. & & do. & Male & & & & 20 & 122 & \\
\hline $\begin{array}{l}\text { Do..... } \\
\text { Do.... }\end{array}$ & & & & & & & & $\begin{array}{l}100 \\
100\end{array}$ & \\
\hline Do.... & & & & & & 170 & (c) & $(c)$ & \\
\hline Billiton: B & 1249 & $\mathrm{~N}$ & & 300 & 101 & & & & \\
\hline orn & & & & & & & 1 & 132 & \\
\hline Do $\ldots . .$. & 1 & & $\ldots$. & 332 & 105 & & & & \\
\hline agi Island & & & & 315 & 101 & & & 1 & \\
\hline & & & & & & & & 10 & \\
\hline & & 1 & & 290 & 98 & & & & \\
\hline ias & & & & & & & & 1] & \\
\hline ias Islands: I & & & & & & & & & \\
\hline & & & & & & & 3 & & \\
\hline & & & & & & & & & \\
\hline io & & & & & & & $=$ & & \\
\hline ias Islands: Siaba B & 121857 & .. do & & & & 370 & 215 & 108 & \\
\hline
\end{tabular}

$a$ These numbers are not interchanged; the antlers are short and very stout and heavy.

$b$ Last upper molar not in place.

$c$ Spike antler.

SUS OI Miller.

Four pigs were secured on the island of Banka, which Mr. Miller has identified as Sus oi. ${ }^{a}$

No pigs were taken by Doctor Abbott on the island of Billiton.

RATUFA POLIA, new species.

1890. Sciurus albiceps Jentink, Notes Leyden Museum, XII, p. 151, March, 1890.

1905. Ratufa albiceps WiLlink, Natuurkundig Tijdschrift Nederlandsch-Indië, XLV, p. 237.

Type.-Adult female, skin and skull, Cat. No. 125004, U.S.N.M., collected at Bukit Menguru, island of Billiton, between Sumatra and Borneo, August 9, 1904, by Dr. W. L. Abbott. Original number 3551.

${ }^{a}$ For a full consideration of these specimens see Notes on Malayan Pigs, by Gerrit S. Miller, jr., Proc. U. S. Nat. Mus., XXX, pp. 741 and 742, June 13, 1906. 
Diagnostic characters.-Like Ratufa ephippium from Borneo, but with a distinctly gray or dirty-white head, sides more grizzled and less reddish.

Solor.-Type: Upper surface of neck, body, and the sides a grizzle of ochraceous (a little lighter than that of Ridgway) and black, the latter predominating in the median line and forming an ill-defined broad streak on the lower back, the ochraceous predominating about the shoulder and anterior half of the sides, the two colors about equally mixed along the posterior half of the sides. Lower throat, uncierparts of body, inner side of legs, ochraceous. Nose, cheeks, insides of ears, and extreme upper part of throat dirty white or cream-buff; top of head a grizzle of black and cream-buff; side of neck for about $10 \mathrm{~mm}$. posterior to ear rather light ochraceous, devoid of black grizzling, extending upward to outer surface of ear, where it becomes buffy. Fringe on outer surface of forearm tawny; fore feet dull ochraceous; outside of foreleg similar to sides of body, inner side ochraceous. Hind feet ochraceous; lower leg and thigh a dark or almost tawny ochraceous, the upper and outer surface of the thigh being encroached on by the grizzling of the sides of the body. Upper surface of tail dark brown, something between Ridgway's burnt umber and seal brown, almost black at the extreme tip; underside of tail similar for outer half of hairs, inner half of hairs dull ochraceous, the short appressed hairs clear ochraceous.

Skull and teeth.-These closely resemble those of specimens of Ratufa ephippium from western Borneo.

Measurements.-Type: Head and body, $345 \mathrm{~mm}$; tail vertebræ, 337; hind foot, 79 (74). Skull of ty pe: Upper length, 64.0 ; basal length, 53.6 ; basilar length, 50.2; palatal length, 29.1; condylo-basal length, 57.8 ; zygomatic breadth, 41.1; interorbital constriction, 27.6 ; constriction behind postorbital processes, 21.8; diastema, 15.5; maxillary tooth row (alveoli), 13.5; mandible, back of condyle to front of symphysis, 41.2; mandibular tooth row (alveoli), 12.7. For measurements of the series see table, page 589 .

Specimens examined.-Thirteen; see table, page 589.

Remarks.-None of the series examined show any marked deviation in color from the type. The amount of white or gray on the head is subject to some variation, being more extensive on the top of the head in some individuals than in others. In Cat. Nos. 124932 and 124974 , U.S.N.M., the tawny-ochraceous of the hind legs is replaced by a sort of dull ochraceous. Only one of the specimens, Cat. No. 125008 , U.S.N.M., is in old worn pelage; the black of its upper parts has been bleached to a dull brown, or brownish black. Some of the other specimens have the tails dull brownish black. On holding Cat. No. 124975 , U.S.N.M., an immature female, in certain lights there can be made out 13 indistinct rings in the tail caused by narrow 
(about $3 \mathrm{~mm}$. wide) terminal and subterminal ferruginous bands on the otherwise black hairs. Some of the other specimens when looked at in certain lights show indistinct annulations on the tail, especially Cat. No, 125008, U.S.N.M., the one in worn pelage, which shows 6 indistinct blackish brown bands on the tail ( $15-30 \mathrm{~mm}$. wide) alternating with the dull brown of the rest of the tail.

Ratufa polia differs from $R$. ephippium in its marked gray head, in which respect it resembles $R$. hypolenca of Sumatra; but in hypolenca the underparts are white, in marked contrast to the sides, and the head is less white. The affinities of Ratufa polia are clearly with the Bornean form.

As Jentink identified the Billiton giant squirrel as Sciurus albiceps Desmarest, the following notes made by Mr. Gerrit S. Miller, jr., on the type in the Paris Museum will prove of interest and show that Ratufa potia needs no comparison with $R$. albiceps:

Ratufa albiceps (Desmarest) type, mounted. Adult female, nursing. On base of stand, "Écureuil à tête blanche de Java, par Leschenault 1808, S. albiceps (Desm.) type." The specimen represents a species I have never seen. In general it may be described as a small bicolor with normal tail, but palliata back so developed that the mantle covers the entire back, sides, and forelegs, allowing the black to appear now here except on front feet, a narrow line along posterior edge of front leg and on hind feet, legs, and thighs, the thighs showing some of the characteristic bicolor speckling; entire head and distal portion of neck white, a fairly well-defined brownish streak $7 \mathrm{~mm}$. wide extending back from ear to join brown of neck. Underparts and inner surface of legs dirty yellowish. The light tips of the hairs of the tail are dirty white without trace of yellow; but the yellow may easily have been bleached out. They are about the normal extent for bicolor. Proximal fifth of tail concolor with hind legs - that is, a mixture of blackish and a dull indefinite brown beneath the surface. Lines of demarcation everywhere well defined except between white of head and colors of back and breast. Ears in bad condition, but apparently whitish inside and brownish outside. Whiskers blackish. Measurements from mounted specimen: Head and body, 350; tail vertebræ, 320; hind foot, 65 (60); outer toe and claw, 21 .

RATUFA POLIA BANCANA, new subspecies.

Type.-Adult male, skin and skull, Cat. No. 124680 U.S.N.M., collected at Tanjong Rengsam, island of Banka, east of Sumatra, May 27, 1904, by Dr. W. L. Abbott. Original number 3277.

Diagnostic characters. - Like Ratufa polia from Billiton, but forefeet lighter in color, less white on head, and teeth smaller.

Color.-Type: Upper surface of neck, body, and the sides a grizzle of ochraceous (a little lighter than that of Ridgway) and brownish or dull black, the latter predominating in the median line, where it forms an ill-defined dark stripe, the two colors equally mixed along the sides. About the shoulder, especially anteriorly and on outer surface of upper arm, the ochraceous is replaced by a dirty white or creambuff color. Lower throat, underparts of body, inner sides of legs, light ochraceous or almost ochraceous-buff. Nose and cheeks, dirty 
white, with dark bases of hairs showing. Top of head, brownish black, rather sparingly sprinkled with dirty white. Inner side of ears and small area in front of ear, cream-buff. Outer side of ear and side of neck for about $10 \mathrm{~mm}$. behind ear ochraceous-buff, devoid of black grizzling. Fringe on outer surface of forearm, light tawny ochraceous; outer side of foreleg a grizzle of dull black and dirty white, dissimilar to sides of body; inner side of foreleg ochraceousbuff, deeper than that of Ridgway; lower foreleg and foot generally buffy. Hind feet, light, ochraceous-buff; inside of hind leg and thigh light ochraceous-buff, the longer hairs bordering the inner side tawny ochraceous. Outer surface of hind leg almost as far as heel similar to sides of body. Upper surface of tail dark brown, something between Ridgway's burnt umber and seal brown; underside of tail, blackish for the outer half or two-thirds of the hairs; inner half of hairs between buff and ochraceous-buff, the short, median appressed hairs ochraceous.

Skull and teeth. - In the great majority of cases Ratufa polia bancana can be readily separated from Ratufa polia by the distinctly shorter length of its tooth row and smaller teeth; but a few of the skulls in the two series can not be so distinguished.

Measurements.-Type: Head and body, $345 \mathrm{~mm}$.; tail vertebræ, 425; hind foot, 76 (71). Skull of type: Upper length, 64.5 ; basal length, 54.0; basilar length, 50.9; condylo-basal length, 58.7; palatal length, 28.7; zygomatic breadth, 39.5 ; interorbital constriction, 26.8 ; constriction behind postorbital processes, 21.6 ; diastema, 15.6; maxillary tooth row (alveoli), 12.1; mandible, back of condyle to front of symphysis, 40.4; mandibular tooth row, 13 . For measurements of the series see table, page 589.

Specimens examined.--Fourteen; see table, page 589.

Remarks. - Most of the specimens of Ratufa polia bancana are in old worn and bleached pelage, so that, in comparing the ser is as a whole with that of Ratufa polia, the two look very different. But by comparing individuals in like stages of wear the differences, while apparent and constant, are not so great. In the Banka animal the fore and hind feet are lighter than they are in the Billiton one; the cheeks and sides of the neck are lighter; the forearm and anterior shoulder area are dirty white grizzled with blackish, instead of ochraceous with black grizzling. In the Banka form the heads are less gray than in the typical form, but, as in the Billiton animal, the amount of light coloring is somewhat variable. Some of the specimens show the indistinct rings on the tails, such as are seen in $R$. polia. 
External and cranial measurements of Ratufas from Banka and Billiton.

\begin{tabular}{|c|c|c|c|c|c|c|c|c|c|c|}
\hline Name. & Locality. & $\begin{array}{l}\text { Num- } \\
\text { ber. }\end{array}$ & Sex. & 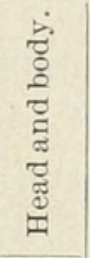 & 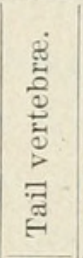 & 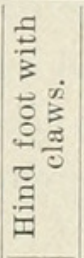 & 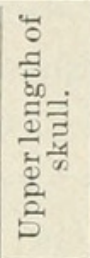 & 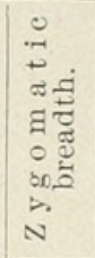 & 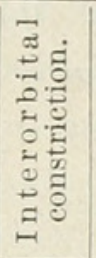 & 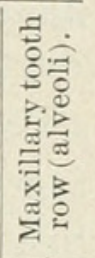 \\
\hline  & 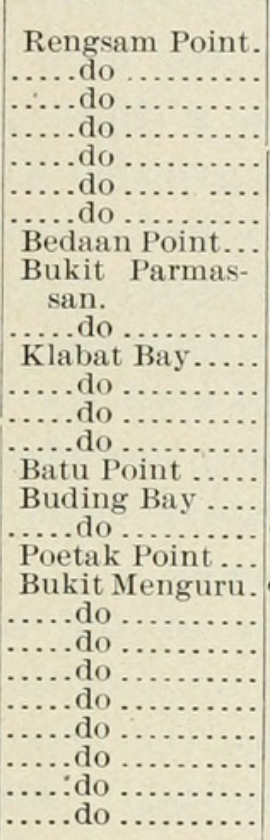 & $\begin{array}{r}124674 \\
124675 \\
124676 \\
124677 \\
124678 \\
124679 \\
a 124680 \\
124743 \\
124748 \\
124749 \\
124868 \\
124869 \\
124870 \\
124871 \\
124932 \\
124974 \\
b 124975 \\
124993 \\
a 125004 \\
125005 \\
125006 \\
125007 \\
125008 \\
125009 \\
125010 \\
125011 \\
125012\end{array}$ & 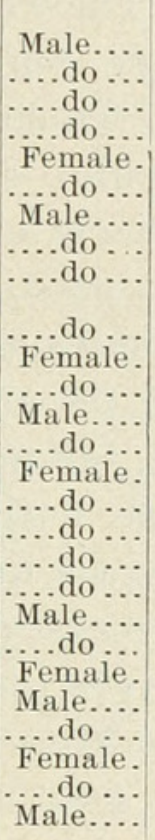 & $\begin{array}{r}m m . \\
325 \\
340 \\
340 \\
340 \\
345 \\
335 \\
345 \\
345 \\
330 \\
\\
340 \\
345 \\
325 \\
335 \\
340 \\
320 \\
340 \\
295 \\
348 \\
345 \\
337 \\
345 \\
335 \\
360 \\
340 \\
330 \\
340 \\
340\end{array}$ & $\begin{array}{l}m m . \\
357 \\
390 \\
415 \\
\cdots 3 . \\
370 \\
370 \\
425 \\
390 \\
340 \\
\\
365 \\
385 \\
380 \\
400 \\
400 \\
370 \\
390 \\
370 \\
385 \\
377 \\
352 \\
390 \\
380 \\
367 \\
380 \\
375 \\
365 \\
375\end{array}$ & $\begin{array}{r}m m . \\
77 \\
81 \\
75 \\
79 \\
78 \\
79 \\
76 \\
77 \\
78 \\
78 \\
81 \\
79 \\
79 \\
77 \\
74 \\
77 \\
76 \\
78 \\
79 \\
77 \\
77 \\
78 \\
81 \\
78 \\
75 \\
71 \\
76\end{array}$ & $\begin{array}{l}64.5 \\
62.7 \\
62.8 \\
62.8 \\
62.8 \\
63.3 \\
59.4 \\
64.5 \\
64.0 \\
61.8 \\
63.2 \\
65.0 \\
63.5 \\
63.9 \\
62.8 \\
64.7 \\
61.8\end{array}$ & $\begin{array}{r}39.0 \\
39.5 \\
39.9 \\
38.9 \\
38.1 \\
40.5 \\
35.7 \\
40.7 \\
41.1 \\
-38.4 \\
39.1 \\
40.2 \\
40.5 \\
40.1 \\
39.5 \\
40.7 \\
40.9\end{array}$ & $\begin{array}{l}m m . \\
25.5 \\
25.3 \\
26.1 \\
24.7 \\
26.2 \\
25.9 \\
26.8 \\
25.8 \\
26.5 \\
26.4 \\
26.6 \\
26.4 \\
26.0 \\
26.5 \\
26.0 \\
27.1 \\
23.0 \\
28.4 \\
27.6 \\
25.7 \\
25.8 \\
26.7 \\
26.7 \\
26.5 \\
26.6 \\
28.2 \\
27.2\end{array}$ & $\begin{array}{l}12.5 \\
12.0 \\
12.0 \\
13.0 \\
13.4 \\
12.7 \\
12.4 \\
13.2 \\
13.5 \\
13.0 \\
12.9 \\
13.4 \\
13.1 \\
13.3 \\
12.8 \\
12.7 \\
12.8\end{array}$ \\
\hline
\end{tabular}

\section{SCIURUS BANGKANUS Schlegel.}

1863. Sciurus prevostii bangkanus Schlegel, Nederlandsch Tijdsch. Dierkunde, I, p. 26 , pl. I, fig. 2 .

1888. Sciurus prevostii Jentink, Mus. d'Hist. Nat. Pays-Bas, XII, Cat. Syst. Mammifères, p. 26.

1905. Sciurus prevostii WiLlınk, Natuurkundig Tijdschrift Nederlandsch-Indië, XLV, p. 240.

For list of specimens and measurements see table, page 591. This series of topotypes differs in color from Schlegel's very good figure as follows: Tawny of the underparts deeper and darker, nearly like Ridgway's tawny; no pronounced black stripe bordering the tawny, the tawny merely much darker with the basal half of the hairs blackish; shoulder slightly more jellowish than in the figure.

\section{SCIURUS MENDANAUUS, new species.}

1890. Sciurus prevostii Jentink, Notes Leyden Museum, XII, p. 149, March 10, 1890.

1905. Sciurus prevostii WrLlink, Natuurkundig Tijdschrift Nederlandsch-Indië, XLV, p. 240.

Type.--Adult male, skin and skull, Cat. No. 124916, U.S.N.M., collected on Pulo Mendanau, west of Billiton Island, Malay Archipelago, July 14, 1904, by Dr. W. L. Abbott. Original number 3475. 
Diagnostic characters.--Similar to Sciums carimatæ Miller, but underparts and shoulder darker. Differs from Sciurus rafflesi in its much lighter shoulder.

Color.-Type: Upper parts of head, neck, and body and a narrow stripe on outer surface of hind leg black. Underparts, fore legs, and feet, and inner surface of hind legs and feet, deep, rich ferruginous, brightest on the throat, darkest on the forearm and on the feet, where the color approaches hazel. The white stripe extends from behind the shoulder to the heel. In the region of the hips it is widest and encroached on by the black, which makes a slight grizzle. Area at base of whiskers and chin, white slightly grizzled with black. Sides of head and neck a fine grizzle of black and white, the former in excess. White spot on cheek indistinct. Shoulder orange-ochraceous, grizzled with black, due to bases of hairs showing, blending in with the deep rich ferruginous of the arm, and with the white of the side stripe. Tail uniformly black, but not so deep and clear as on the back.

Skull.-Not distinguishable with certainty from that of Sciurus carimatx; maxillary tooth row a little longer.

Measurements.-External measurements of the type: Figures in parentheses are measurements of a cotype of Sciurus rafflesi (No. 84.6, 3.8, Sumatra Raffles-British Museum) and the type of S. carimatx. Total length, $448 \mathrm{~mm}$. (- -428$)$; head and body, $238(-, 243)$; tail vertebræ, $210(-, 185)$; hind foot with claws, $55(56,52)$; hind foot without claws, $51(51,47)$.

Cranial measurements of the type, of a cotype of $S$. rafflesi and the type of S. carimatx: Greatest length, $54 \mathrm{~mm}$. $(55,53.5)$; basal length, 46.5 (48.6, 46.5); basilar length, 43.5 (45.6, 43.5); palatilar length, 23.5 $(24.8,23)$; diastema, $13.5(13.6,13)$; zygomatic breadth, $33(31,32.5)$; interorbital constriction, $22(23,21)$; least depth of ramus of mandible in front of tooth row, $5(5,5)$; maxillary tooth row (alveoli), 11.25 $(11.4,10)$; mandibular tooth row, $11(11.4,10)$.

Specimens examined.- See table, page 591.

Remarks.--The series of specimens is very uniform in color and pattern, and none show any deviation from the type. Sciurus mendanaus is easily distinguishable from $S$. carimatx by its darker shoulder and underparts and by the greater length of the tooth rows of the skulls. From S. rafflesi of Sumatra it differs in its slightly smaller size and much lighter shoulder. Mr. Miller, in comparing specimens of $S$. melanops with cotype No. 84.6, 3.8 of $S$. rafflesi from Sumatra, in the British Museum, noted that the shoulder in the latter has the palest red, about the same in color as the darkest at the side of the wrist of a specimen of S. melanops (Cat. No. 113153, U.S.N.M.) - that is, a deep rich ferruginous of Ridgway. His notes do not show whether or not the shoulder of $S$. rafflesi is grizzled as it is in $S$. mendanaus, but if it is he would hardly have failed to remark on 
it in comparing it with $S$. melanops, in which the shoulder is not grizzled. In pattern and color S. mendanauus is nearly identical with $S$. bangkanus; the shoulder in the latter is lighter and in some specimens inciining to grayish, but the Banka squirrel is much larger. See table, page 591 .

External and cranial measurements of Sciurus bangkanus and of Sciurus mendanauus.

\begin{tabular}{|c|c|c|c|c|c|c|c|c|c|}
\hline Name. & Locality. & $\begin{array}{l}\text { Num- } \\
\text { ber. }\end{array}$ & Sex. & 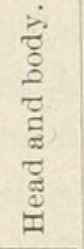 & 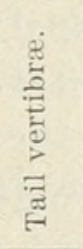 & 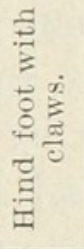 & 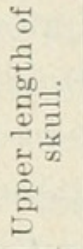 & 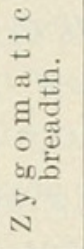 & 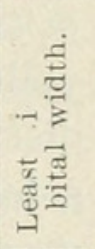 \\
\hline 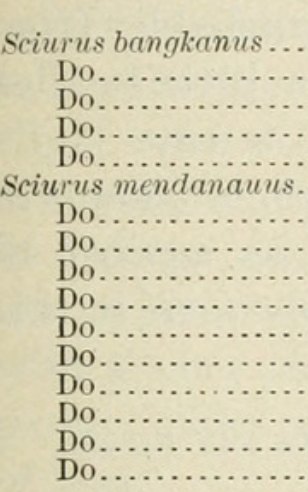 & 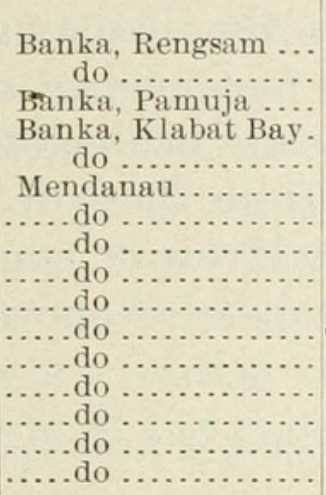 & $\begin{array}{r}124681 \\
124682 \\
124762 \\
124872 \\
124873 \\
124911 \\
124912 \\
124913 \\
124914 \\
124915 \\
\alpha 124916 \\
124917 \\
b 124918 \\
b 124919 \\
124920 \\
124921\end{array}$ &  & $\begin{array}{r}m m . \\
269 \\
268 \\
264 \\
270 \\
272 \\
235 \\
235 \\
230 \\
245 \\
230 \\
238 \\
238 \\
270 \\
260 \\
230 \\
237\end{array}$ & $\begin{array}{l}m m . \\
245 \\
265 \\
268 \\
270 \\
280 \\
212 \\
215 \\
220 \\
210 \\
218 \\
210 \\
205 \\
210 \\
205 \\
204\end{array}$ & $\begin{array}{r}m m . \\
60 \\
61 \\
62 \\
60 \\
62 \\
57 \\
58 \\
56 \\
57 \\
55 \\
55 \\
53 \\
54 \\
56 \\
55 \\
55\end{array}$ & $\begin{array}{l}m m . \\
57.0 \\
58.0 \\
58.0 \\
59.0 \\
60.0 \\
54.0 \\
52.0 \\
54.0 \\
55.0 \\
54.0 \\
53.5 \\
53.0 \\
\cdots . . . \\
52.0 \\
53.0\end{array}$ & $\begin{array}{l}m m . \\
35.5 \\
37.0 \\
36.0 \\
35.0 \\
37.0 \\
32.0 \\
33.0 \\
34.0 \\
34.0 \\
34.0 \\
33.0 \\
32.5 \\
\ldots . . . \\
33.0 \\
33.0\end{array}$ & $\begin{array}{l}\mathrm{mm} . \\
24.0 \\
34.5 \\
24.5 \\
24.0 \\
24.0 \\
22.0\end{array}$ \\
\hline
\end{tabular}

a Type.

$b$ Alcoholic.

SCIURUS TEDONGUS, new species.

1888. Sciurus badjing Jentink, Mus. d'Hist. Nat. Pays-Bas, XII, Cat. Syst. Mammifères.

1905. Sciurus notatus WiLLINk, Natuurkundig Tijdschrift Nederlandsch-Indië, LXV, p. 240.

Type--Adult male, skin and skull, Cat. No. 124717, U.S.N.M., collected at Tanjong Tedong, island of Banka, east of Sumatra, June 1, 1904, by Dr. W. L. Abbott. Original number 3285.

Diagnostic characters. - Similar to Sciurus peninsularis Miller, from the Malay Peninsula and eastern Sumatra, but white and black stripes along side not so broad and clear. Outer surface of legs and upper surface of fset with a slight suffusion of the orange-rufous of the underparts, found to a slight extent only in S. peninsularis, and to the same extent in S. billitonus. Differs from S. billitonus only in shorter length of maxillary tooth row and tendency for tip of tail to be redder.

Color.--Type: Upper. parts and tail a fine grizzle of black and ochraceous-buff, inclining toward olive-buff on the tail, the two colors in about equal proportions. Underparts and inner surface of legs ochraceous rufous. A slight wash of this color extends on the outer surface of the legs, becoming marked on the upper surface of the feet. Lateral stripes as in Sciurus vittatus (comparison with specimens from 
Tapanuli Bay, western Sumatra), the outer about $3 \mathrm{~mm}$. wide at the middle, dirty buff in color; the inner about $5 \mathrm{~mm}$. wide, black, with a slight grizzling of the ochraceous rufous of the underparts. Sides of head and under surface of tail similar in color to outer surfaces of legs. Measurements. - See table, page 592.

Specimens examined.-Eleven; see table, page 592.

Remarks.-This squirrel is distinguishable in color from Sciuris vittatus (specimens from Tapanuli Bay, western Sumatra) by its less yellow cheeks and distinctly rufous feet. From S. peninsularis it is distinguished by the narrow dirty buff instead of whitish cream-buff side stripe and by the narrower less clear black side stripe and the greater suffusion of the ochraceous rufous of the underparts on the feet. Skins of $S$. tedongus are practically indistinguishable from those of S. billitonus, though the hind foot averages a little smaller (see table p. 592) and the tips of the tails are inclined to tawny.

The skulls of Sciums tedongus differ from those of S. billitonus in the shorter length of the maxillary tooth row $(9 \mathrm{~mm}$. as against 10 $\mathrm{mm}$.), but are indistinguishable from skulls of $S$. peninsularis in this respect.

External and cranial measurements of plantain squirrels from Banka and Billiton.



$a$ Type.

$b$ Alcoholic.

$c$ No skin.

$d$ Not fully adult.

SCIURUS BILLITONUS, new species.

1890. Sciurus notatus Jentink, Notes Leyden Museum, XII, March 12, 1890, p. 152.

1905. Sciurus notatus WILlınk, Natuurkundig Tijdschrift Nederlandsch-Indië, LX V, p. 240. 
Type.-Adult female, skin and skull, Cat. No. 124977, U.S.N.M., collected at Buding Bay, island of Billiton, between Sumatra and Borneo, August 5, 1904, by Dr. W. L. Abbott. Originalnumber 3539.

Diagnostic characters. - Similar to Sciurus peninsularis and to S. tedongus. Black and white stripes on sides not so wide and clear as in S. peninsularis. Tip of tail not so much inclined to reddish as in either. Outer surface of legs and upper surface of feet suffused with orange-rufous of underparts as in $S$. tedongus, much more than in $S$. peninsularis. Maxillary tooth row averaging about $1 \mathrm{~mm}$. longer than in S. peninsularis, vittatus or tedongus.

Color.-Type: Upper parts and tail a fine grizzle of black and a color lying between ochraceous-buff and a pale tawny olive; the black rather in excess on the body, and the two about equally mixed in the tail. Underparts and inner surface of legs ochraceous rufous. A slight wash of this color extends on the outer surfaces of the legs, becoming marked on the upper surface of the feet. Lateral stripes as in Sciums vittatus from Tapanuli Bay, Sumatra, the outer about 3 $\mathrm{mm}$. wide at the middle, dirty buff, the inner about $7 \mathrm{~mm}$. wide, black with a very slight grizzling of the ochraceous rufous of the underparts. Sides of head and under surface of tail similar to outer surface of legs.

Measurements.-See table, page 592.

Specimens examined.-Thirteen; see table, page 592.

Remarks. - This squirrel is distinguishable in color from Sciurus vittatus (Tapanuli Bay, Sumatra) by its less yellow cheeks and distinctly rufous feet. From S. peninsularis it is distinguished by the narrow dirty buff instead of whitish cream-buff side stripe and by the narrower, less clear, black stripe and the greater suffusion of the ochraceous rufous of the underparts on the feet and by the greater length of the maxillary tooth row. Skins of S. billitonus are almost indistinguishable from skins of $S$. tedongus, but the hind foot averages a little longer (see table, page 592), and the tips of the tails are not so much inclined to reddish. The skulls of the Banka and Billiton squirrels are easily separable by the greater length of the maxillary tooth row of the latter. (See table, page 592.)

\section{SCIUROPTERUS VORDERMANNI Jentink.}

1890. Sciuropterus vordermanni Jentink, Notes Leyden Museum, XII, p. 150, pl. viI, figs. 13 and 14, March, 1890.

1905. Sciuropterus vordermanni WILlink, Natuurkundig Tijdschrift NederlandschIndië, LX V, p. 233.

Doctor Abbott secured one specimen, an adult female, at Buding Bay, Billiton. Its colors differ in no essential respects from those given in the original description. The skull is exactly like the figures of the type. Measurements: Cat. No. 124986, U.S.N.M. Head and body, $103 \mathrm{~mm}$.; tail vertebræ, 100; tail to end of hairs, 113; hind foot with

Proc. N. M. vol. xxxi-06-39 
claws, 22; ear from meatus, 12; greatest length of skull, 29; nasals, median line, 8 ; greatest breadth of skull, 17.3 ; diastema, 5.6; length of upper molar series, 5.5 .

\section{NANNOSCIURUS BANCANUS Lyon.}

1888. Sciurus soricinus Jentink, Mus. d'Hist. Nat., XII, Cat. Syst. Mammifères, p. 25.

1905. Nannosciurus melanotis WILlink, Natuurkundig Tijdschrift NederlandschIndië, LXV, p. 249.

1906. Nannosciurus bancanus Lyon, Proc. Biol. Soc., Washington, XIX, p. 55, May 1, 1906.

Represented by 12 specimens, all from the island of Banka. None were secured on Billiton. For table of measurements of this and related species, see page 594 .

External and cranial measurements of pigmy squirrels from Sumatra, Borneo, Java, Sinkep, and Banka.

\begin{tabular}{|c|c|c|c|c|c|c|c|c|c|}
\hline Name. & Locality. & $\begin{array}{l}\text { Num- } \\
\text { ber. }\end{array}$ & Sex. & 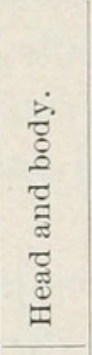 & 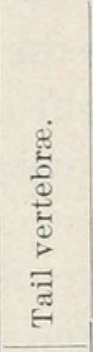 & 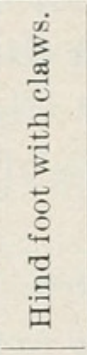 & 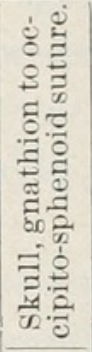 & 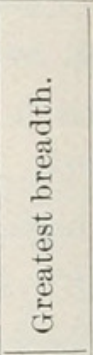 & 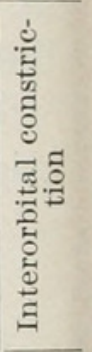 \\
\hline - & & & & & & & & & \\
\hline Nannosciurus bancanus... & Point Tedong .... & 124718 & Male. & 83 & 65 & 23.0 & 15.4 & 15.7 & 10.0 \\
\hline Do................. & Klabat Bay ....... & 124875 &  & 85 & 70 & 22.5 & 15.7 & 15. & 10.0 \\
\hline & ..... do... & 124876 & 0 & 80 & 70 & 22.5 & 14.9 & 16.0 & 10.2 \\
\hline $\begin{array}{l}\mathrm{D} \\
\mathrm{D}\end{array}$ & 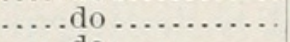 & 124877 & ds & 78 & 65 & 23.6 & 14.8 & 16.4 & 10.3 \\
\hline $\begin{array}{l}\mathrm{D} \\
\mathrm{D}\end{array}$ & 0 & 1248 & & 90 & 60 & 22.3 & 15.0 & & 9.7 \\
\hline $\begin{array}{l}\mathrm{D} \\
\mathrm{D}\end{array}$ & . do & 124879 & $\ldots . d$ & 85 & 70 & 23.9 & 14.9 & 16.2 & 10.0 \\
\hline D & 8 & a 124880 & Fema & 82 & 63 & 22.0 & 14. 9 & & 10.1 \\
\hline $\mathrm{D}$ & . & 124881 & ...do & 80 & 67 & 22.5 & 15.5 & 16.0 & 10.0 \\
\hline $\mathrm{D}$ & . & $\begin{array}{l}124882 \\
124883\end{array}$ & $\begin{array}{l}\text { Male } \\
\text { do }\end{array}$ & $\begin{array}{l}85 \\
80\end{array}$ & $\begin{array}{l}65 \\
65\end{array}$ & $\begin{array}{l}22.9 \\
23.5\end{array}$ & 15.5 & 16.1 & 10.0 \\
\hline Do... & d & 124884 & & 82 & 70 & 22.4 & 15.0 & 16.2 & 10.2 \\
\hline $\begin{array}{l}\text { Do.......................... } \\
\text { Nannnosciurus borneanus. }\end{array}$ & do & 142258 & & & & & 15.6 & 14.9 & 10.0 \\
\hline $\begin{array}{r}\text { Nannnosciurus borneanus. } \\
\text { Do........................ }\end{array}$ & Western Borneo.. & 142259 & . do & 75 & 65 & 22.5 & 14. 7 & & \\
\hline ……... & $\ldots$. do $\ldots . . . \cdots$ & $\begin{array}{l}142260 \\
142261\end{array}$ & 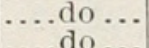 & $\begin{array}{l}85 \\
80\end{array}$ & $\begin{array}{l}68 \\
65\end{array}$ & 23.0 & 154 & 16.2 & 10.0 \\
\hline Do & $\begin{array}{l}\cdots \\
\cdots\end{array}$ & $\begin{array}{l}142261 \\
142262\end{array}$ & $\cdots$ & $\begin{array}{l}80 \\
82\end{array}$ & $\begin{array}{l}65 \\
64\end{array}$ & $\begin{array}{l}23.3 \\
23.5\end{array}$ & $\begin{array}{l}15.5 \\
14.8\end{array}$ & $\begin{array}{l}16.1 \\
15.0\end{array}$ & $\begin{array}{l}10.5 \\
10.0\end{array}$ \\
\hline Do... & do & 142263 & & 77 & 65 & 23.7 & 15.0 & $\begin{array}{l}10.0 \\
15.8\end{array}$ & 10.2 \\
\hline Do... & $\cdots$ & 142265 & & 85 & 70 & 23.9 & $\cdots \ldots$ & ....... & ...... \\
\hline Do.... & .. & 142266 & $d \rho$ & 80 & 64 & 22.0 & & & \\
\hline Do.... & 0 & 142267 & do & $\begin{array}{l}83 \\
78\end{array}$ & 45 & $\begin{array}{l}23.0 \\
20\end{array}$ & 156 & 160 & \\
\hline $\begin{array}{l}\mathrm{D} \\
\mathrm{D}\end{array}$ & $d$ & $\begin{array}{l}142268 \\
142269\end{array}$ & $\cdots$ & 90 & $\begin{array}{l}00 \\
57\end{array}$ & 23.9 & $\begin{array}{l}10.0 \\
14.7\end{array}$ & $\begin{array}{l}16.0 \\
15.9\end{array}$ & $\begin{array}{l}10.5 \\
10.5\end{array}$ \\
\hline Do......... & $d$ & a 142271 & Fem & 86 & 65 & 22.6 & 15.6 & 16.8 & 10 \\
\hline Nannosciurus pulcher. & Sinkep Island .... & a113131 & & 88 & & 23.3 & 16.4 & & 11.5 \\
\hline Do.... & ..... do & 123098 & Male & 85 & 75 & 23.7 & 16.4 & 16.7 & 10.0 \\
\hline Do.... & ....... & 123099 & & 95 & 70 & 23.3 & 16.7 & 17.2 & 10.3 \\
\hline Nannosciurus sumatranus. & $\begin{array}{l}\text { Tarussan Bay, Su- } \\
\text { matra. }\end{array}$ & a141058 & Male ... & 83 & 72 & 23.8 & 15.0 & 15.8 & \\
\hline Nannosciurus melanotis... & Batavia...... & 121494 & Female. & & & 22.5 & 16.0 & 16.5 & 10.0 \\
\hline  & $\begin{array}{l}\ldots . \text { do } \\
\ldots . . .\end{array}$ & $\begin{array}{l}121495 \\
121496\end{array}$ & Mal & & & $\begin{array}{l}22.7 \\
22.2\end{array}$ & $\begin{array}{l}15.5 \\
15.5\end{array}$ & $\begin{array}{l}16.5 \\
15.9\end{array}$ & $\begin{array}{r}9.5 \\
10.0\end{array}$ \\
\hline & & & & & & & & & \\
\hline
\end{tabular}

a Type.

MUS FIRMUS Miller.

Five large gray rats, secured on Banka, show no appreciable differences from Mus firmus Miller, from Linga. No rats of this group were obtained on Billiton. For table of measurements, see page 595 . 


\section{MUS CREMORIVENTER Miller.}

Three rats of this group were collected on Banka and one on Billiton. They are not appreciably different from Mus cremoriventer Miller, of the Malay Peninsula. The Banka specimens are not fully adult; the scales on the tails are a little smaller and the teeth a little larger than they are in the Billiton specimen. The material is too limited for arriving at any positive conclusions. For measurements, see table page 595 .

External and cranial measurements of Mus firmus and Mus cremoriventer.

\begin{tabular}{|c|c|c|c|c|c|c|c|c|c|}
\hline Name. & Locality. & $\begin{array}{l}\text { Num- } \\
\text { ber. }\end{array}$ & Sex and age. & 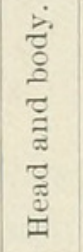 &  & 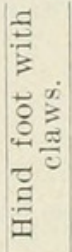 & 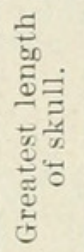 & 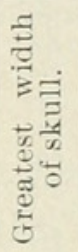 & 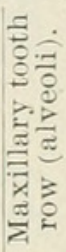 \\
\hline Mus firmus.. & $\begin{array}{l}\text { Banka; Tanjong Reng- } \\
\text { sam. }\end{array}$ & 124690 & Female, adult... & mm. & $\begin{array}{l}m m . \\
\cdots \cdots\end{array}$ & $m m$ & $\begin{array}{l}m m . \\
52.6\end{array}$ & $\begin{array}{l}m m . \\
26.2\end{array}$ & $\begin{array}{c}m m \\
9.5\end{array}$ \\
\hline $\begin{array}{l}\text { Do...... } \\
\text { Do..... }\end{array}$ & & $\begin{array}{l}124691 \\
124692\end{array}$ & $\begin{array}{l}\text { Male, adult....... } \\
\text { Female, sduit... }\end{array}$ & $\begin{array}{l}247 \\
243\end{array}$ & $\begin{array}{l}307 \\
273\end{array}$ & $\begin{array}{l}50 \\
49\end{array}$ & $\begin{array}{l}54.3 \\
52.6\end{array}$ & $\begin{array}{l}26.1 \\
26.3\end{array}$ & $\begin{array}{l}9.4 \\
9.3\end{array}$ \\
\hline $\begin{array}{l}\text { Do } \\
\text { Do. }\end{array}$ & Banka; Klabat Bay & $\begin{array}{l}124885 \\
124886\end{array}$ & Male, young....... & 190 & 209 & 45 & 45.7 & 21.6 & 9.4 \\
\hline $\begin{array}{l}\text { Mus cremori- } \\
\text { venter. }\end{array}$ & $\begin{array}{l}\text { Banka; Tanjong Reng- } \\
\text { sam. }\end{array}$ & $\begin{array}{l}124800 \\
124695\end{array}$ & $\begin{array}{l}\text { Female, imm a- } \\
\text { ture. }\end{array}$ & $\begin{array}{l}195 \\
113\end{array}$ & $\begin{array}{l}218 \\
153\end{array}$ & $\begin{array}{l}46 \\
25\end{array}$ & 30.3 & 14.6 & 5.9 \\
\hline Do... & Banka; Klabat Bay . & 124887 & & & & & 30.0 & 14. 0 & \\
\hline $\begin{array}{l}\text { Do } \ldots \ldots \ldots \\
\text { Do......... }\end{array}$ & Billiton; Bukit Menguru & $\begin{array}{l}124889 \\
125021\end{array}$ & $\begin{array}{l}\text { Male, immature. } \\
\text { Male, adult....... }\end{array}$ & $\begin{array}{l}105 \\
134\end{array}$ & $\begin{array}{l}136 \\
182\end{array}$ & $\begin{array}{l}26 \\
26\end{array}$ & & $\begin{array}{l}13.8 \\
15.2\end{array}$ & 5.7 \\
\hline
\end{tabular}

MUS NEGLECTUS Jentink.

Doctor Abbott secured the young of a medium-sized rat at Tanjong Poetak, Billiton, which may be referred to this species provisionally. It is so young that the second molars are scarcely up. No rat of this group was taken on Banka.

\section{MUS ASPER Miller.}

Good series of this species were obtained on both Banka and Billiton. Considerable individual variation is seen in the color of the underparts. In some specimens it is almost entirely white or whitish gray, while in others it is very completely washed over with ochraceous buff. The series from the two islands differ in no way from each other nor from specimens from the Malay Peninsula. See table of measurements, page 596 . 
Measurements of Mus asper.

\begin{tabular}{|c|c|c|c|c|c|c|c|c|}
\hline Locality. & $\begin{array}{l}\text { Num- } \\
\text { ber. }\end{array}$ & Sex. & 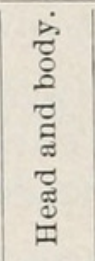 &  & 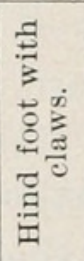 & 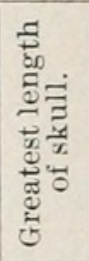 & 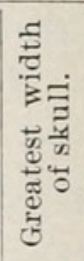 &  \\
\hline Banka; Bukit Parmissan & 124750 & Male adult & $\begin{array}{c}m m . \\
\ldots \ldots\end{array}$ & $\begin{array}{c}m m . \\
\ldots \ldots\end{array}$ & $m m$. & $\begin{array}{l}m m . \\
30.0\end{array}$ & & $\begin{array}{r}m m . \\
5.5\end{array}$ \\
\hline Banka; Tanjong Pamuja. & 124763 & ..... do ... & 129 & 116 & 31.0 & 31.7 & 14.9 & 5.4 \\
\hline Do $\ldots \ldots \ldots$ & 124764 & .....do. & 147 & 116 & 29.5 & & & \\
\hline Do & 124765 & do & & & & 33.0 & 15.0 & \\
\hline Banka; Klabat Bay & 124896 & do & 130 & 109 & 29.5 & & 15.0 & 5.4 \\
\hline Do $\ldots \ldots$..... & 124897 & ..... do . & 140 & 115 & 26.5 & 32.7 & & \\
\hline Banka; Tanjong Rengsam & 124693 & Female adult & 137 & 120 & 28.0 & 33.6 & 14.8 & \\
\hline Banka; Bukit Par & 124751 & ..... do ..... & & & ........ & 29.8 & 14.0 & 5. 1 \\
\hline Banka; Klabat Bay & 124894 & do & & & & 30.5 & 14.6 & 5.0 \\
\hline Do $\ldots \ldots \ldots$ & 124895 & ..do . & 120 & 95 & 28.0 & 30.5 & 14.6 & 5.4 \\
\hline Do .... & 124898 & ..do. . & 139 & 113 & 28.0 & 34.5 & 15.3 & 5. \\
\hline Do & 124899 & . do ... & 130 & 118 & 28.0 & 33.7 & 14.9 & 5.5 \\
\hline Do & 124900 & do ... & 141 & 119 & 27.5 & 32.4 & 14. 7 & 5.1 \\
\hline Do & 124901 & do & 141 & 121 & 28.0 & 33.7 & 14.9 & 5.0 \\
\hline Billiton; Buding Bay & 124978 & Male adult & 117 & 109 & 28.5 & 31.9 & 14.5 & \\
\hline Do .................... & 124979 & ..... do ..... & & & & 32.8 & & \\
\hline Do & 124981 & ..... do .... & 121 & & 27.0 & 31.4 & 14.0 & 5 \\
\hline Billiton; Bukit Menguru . & 125015 & ..... do .... & 124 & 102 & 27.0 & & 13.5 & 5.0 \\
\hline Do $\ldots \ldots \ldots$ & 125016 & ..... do ......... & 135 & 119 & 29.0 & 32.8 & 14.6 & 5.5 \\
\hline Do & 125017 & ..... do ... & 134 & 112 & 29.0 & & 15.0 & 5.0 \\
\hline Do & 125018 & ....... do $\ldots$ & 10 & 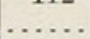 & ....... & 31.0 & 14.2 & 5.0 \\
\hline Billiton; Buding Ba & 124982 & Female adult. & & & & 32.1 & 14.8 & \\
\hline Billiton; Bukit Menguru & 125013 & ..... do .......... & 135 & 123 & 29.0 & 32.2 & 14.4 & 5.2 \\
\hline Do $\ldots \ldots \ldots \ldots \ldots$ & 125014 & ..... do .... & 130 & 115 & 27.0 & 33.7 & 15.2 & 5.3 \\
\hline
\end{tabular}

MUS CLABATUS, new species,

Type.-Old adult female, skin and skull, Cat. No. 124888, U.S.N.M., collected at Klabat Bay, island of Banka, east of Sumatra, June 25, 1904, by Dr. W. L. Abbott. Original number 3439.

Diagnostic characters. - A member of the Mus concolor group, most like Mus surdus Miller from Simalur Island, from which it is indistinguishable externally, but differing from it and the other members of the group in the shape of the external plate of the infraorbital foramen. This plate in Mus clabatus is narrow antero-posteriorly and its anterior edge is inclined backward instead of ascending vertically.

Color.-Type: Entire upper parts and sides, a coarse ill-defined grizzle of dull ochraceous buff and blackish brown, the former more conspicuous along the sides. Underparts and inner surface of limbs a dirty grayish white. A fairly well-defined line of demarcation between the color of the sides and the belly. Ear's, brownish, darker externally, lightly sprinkled with fine brownish hairs inside and out. Feet dirty white. Tail dark uniformly brownish, twelve scales to the centimeter along the middle. Three brownish hairs subtend each scale and about middle of tail equal in length $1 \frac{1}{4}$ scales; at tip of tail they equal about 2 scales in length.

Mammæ.--Inguinal 2-2; pectoral 2-2=8.

Skull and teeth.-The skull differs from that of all the members of the Mus concolor group that I have examined in the narrow external plate of the infraorbital foramen. The anterior edge of this plate 
slopes backward and does not project antero-superiorly in a well-marked rounded angle. The audital bulla in Mus clabatus is more compressed laterally and deeper dorso-ventrally than it is in the other members of the concolor group. The teeth are much worn in the single specimen. Compared with the type of M. surdus the last upper molar is reduced in size.

Measurements.-Type: Total length, $281 \mathrm{~mm}$; head and body, 143; tail vetebræ, 138; hind foot, 25; greatest length of skull, 31; palatal length, 17.1; palatilar length, 15.3; zygomatic breadth, 14.9; interorbital constriction, 5.0; nasals, 10.9 ; diastema, 9.9 ; width of external plate of infraorbital foramen at middle, 3.7 (in $M$. surdus, type, 4.2); maxillary tooth row (alveoli), 5.6; mandible, condyle to front of symphysis, 18.2; mandibular tooth row (alveoli), 5.2.

Specimens examined.-One, the type.

Remarks.--Mus clabatus, while indistinguishable externally from M. surdus, is easily separable by the shape of the external plate of the infraorbital foramen, not only from it, but also from Mus concolor of the Malay Peninsula, from Sumatran and Bornean forms of concolor and from Mus pullus from Tioman Island.

\section{VIVERRA TANGALUNGA Gray.}

1905. Viverra tangalunga Willink, Natuurkundig Tijdschrift NederlandschIndië, LXV, p. 210.

Two individuals were collected by Doctor Abbott on the island of Billiton. None were taken on Banka. For table of measurements, see page 600 .

PARADOXURUS HERMAPHRODITUS (Pallas, in Schreber).

Two Paradoxures were secured in the island of Banka. They show no appreciable differences in respect to color and to shape and size of skull and teeth from specimens of Paradoxurus hermaphroditus from the Malay Peninsula. For table of measurements, see page 600.

PARADOXURUS CANESCENS, new species.

Type--Skin and skull of adult male, Cat. No. 124943 U.S.N.M., collected at Tanjong Batu, island of Billiton, between Sumatra and Borneo, July 19, 1904, by Dr. W. L. Abbott. Original number 3520.

Diagnostic characters. - Similar to Paradoxurus phitippinensis, of the Philippine Islands and Borneo, but with a decided gray color about the head and the anterior third of the body.

Color.-Type: Sides of nose and region of base of whiskers, whitish cream buff; nose and top of nose back as far as line connecting inner canthus of eyes, brownish black, which color extends as a ring about $5 \mathrm{~mm}$. wide around the eye and downward to the lips for a width of 10-12 mm. behind base of whiskers. Ill-defined spot under eye dirty 
white, blending into the color of the cheeks which are a grizzle of dirty white and dull black. A small ill-defined blackish spot is found 15-20 mm. posterior to outer canthus of eye. Area between eyes and line connecting anterior edges of ears an indefinite dirty white with a slight amount of the blackish of the bases and the tips of the hairs showing. This dirty white color with almost no blackish showing extends backward along the side of the head, under the ear and above the dark cheek area and spot. Top of head, between ears, an equal indefinite mixture of dirty white and dull black. (In Paradoxurus philippinensis this region is black.) Ears dull blackish on the outside and with a few dirty white hairs on the inside. Anterior third of upper parts of body, top and sides of neck, an indefinite mixture of cream buff and black, the underfur and basal 5 or $6 \mathrm{~mm}$. of the hairs being blackish, the middle $5 \mathrm{~mm}$. of the hairs being cream buff, and the terminal $5 \mathrm{~mm}$. black. The posterior two-thirds of the upper parts and basal fourth of the tail is generally similar to the anterior portion of the upper parts, but with the cream buff replaced by buff. A fairly well-defined median blackish stripe about $7 \mathrm{~mm}$. wide is found along the lower two-thirds of the back, on each side of which are seven or eight ill-defined spots in a longitudinal row. Outer surfaces of thighs and upper portions of the forelegs similar in color to the anterior third of the body. Fore and hind feet and terminal three-fourths of tail dull black or brownish black. Chin, throat, and anterior underparts and inner side of thighs and forelegs dirty white or cream buff, the blackish bases of the hairs showing through everywhere. Rest of underparts, generally dark buffy, and the dark bases of the hairs less conspicuous.

Skull and teeth.- The skull and teeth of Paradoxurus canescens are a trifle smaller than they are in specimens of $P$. philippinensis from Borneo. Many specimens of $P$. hermaphroditus from the Malay Peninsula show that there is much variation in regard to size of skull and teeth, so that the slightly smaller size of the Paradoxure from Billiton may not be specific.

Measurements of the type.-Head and body, $510 \mathrm{~mm}$.; tail vertebræ, 385 ; hind foot with and without claws, 78, 75; greatest length of skull, 99.3; upper length, 90.7; basal length, 93; basilar length, 90.5; condylo-basal length, 98; palatal length, 43.7; zygomatic breadth, 57.2; breadth of brain case above roots of zygomata, 33.6 ; interorbital constriction, 11.1; front of canine to back of last molar (alveoli), 36; mandible, condyle to front of symphysis, 71.5; front of canine to back of last molar (alveoli), 38.6.

Specimens examined. - Three, all from Billiton; the type, an adult male from Tanjong Batu, an adult female from the same place, and an adult female from Bukit Menguru. 
Remarks.-Paradoxurus canescens is generally lighter in color and grayer in the anterior portions than any other species I have seen. In grayness of head it is approached by $P$. brunnipes Miller, but the brown feet of the latter are distinctive. None of the other species have the distinct gray area between the ears that $P$. canescens has.

\section{ARCTOGALIDIA MINOR, new species.}

Type--Adult female, skin and skull, Cat. No. 124984, U.S.N.M., collected at Buding Bay, island of Billiton, between Borneo and Sumatra, August 3, 1904, by Dr. W. L. Abbott. Original number, 3532.

Diagnostic characters.-A dwarf form of Arctogalidia stigmatica, similar in color and markings to A. fusca Miller from Pulo Kundur, but distinctly smaller.

Color.-Type: General color above most like Ridgway's smoke-gray; under fur and bases of hairs dark broccoli brown, subapical band on hairs, dirty white; apical ring, blackish brown. Three fairly welldefined blackish lines, $4-5 \mathrm{~mm}$. wide extend along the middle of the back, from region of shoulders nearly to root of tail. Head, generally dull blackish, faintly grizzled between the eyes with buffy white. Ears blackish. Side of neck posterior to ears and in front of shoulder, buffy white. Feet blackish. Underparts generally an indefinite, dirty gravish color; in the inguinal region, clay color. Basal third of tail above and below similar to back, distal two-thirds blackish.

Skull and teeth.-These differ from those of related species in their smaller size. Greatest length of skull, $87.5 \mathrm{~mm}$.; type of Arctogalidia fusca, 98.5; adult male, Cat No. $1423 \pm 1$ U.S.N.M, from western Borneo, 110.8 ; greatest width of skulls, respectively, $46.7 ; 62.3 ; 67.4$.

Measurements of type.-Head and body, $440 \mathrm{~mm}$; tail vertebræ, 435 ; hind foot, with and without claws, 74,68 ; greatest length of skull, 87.5 ; upper length, 80.5 ; basal length, 81.5 ; basilar length, 79 ; condylobasal length, 86 ; palatal length, 47.5 ; zygomatic breadth, 46.7 ; width of brain case above roots of zygomata, 30.3; interorbital constriction, 10 ; front of canine to back of last upper molar, 31.8; mandible, condyle to front of symphysis, 64.3; front of canine to back of last lower molar (alveoli), 34.8.

Specimens examined.-One, the type.

Remarks.-Arctogalidia minor needs no comparison with other species of the genus as it is at once told by its small size. 
Measurements of speeimens of Paradoxurus, Viverra, and Arctogalidia from Banka and Billiton.

\begin{tabular}{|c|c|c|c|c|c|c|c|c|c|}
\hline Name. & $\begin{array}{l}\text { Num- } \\
\text { ber. }\end{array}$ & Sex. & 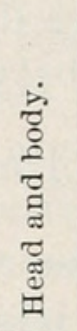 &  & 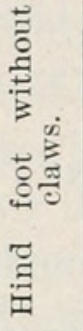 & 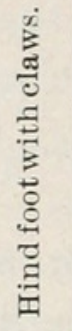 & 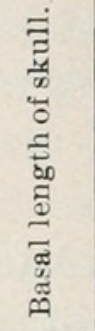 & 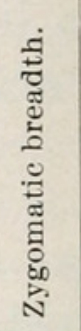 & 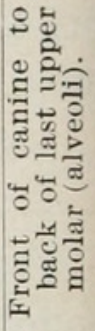 \\
\hline $\begin{array}{l}\text { Paradoxurus hermaphro- } \\
\text { ditus. }\end{array}$ & 124864 & Female adult..... & $\begin{aligned} m m \\
525\end{aligned}$ & ${ }_{440}^{m}$ & ${ }_{78}$ & $\mathrm{~mm}_{80}$ & $\begin{array}{l}m m . \\
95.7\end{array}$ & $\begin{array}{l}m m \\
54.2\end{array}$ & $\begin{array}{l}m m . \\
36.2\end{array}$ \\
\hline 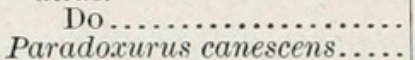 & $\begin{array}{r}124902 \\
a 124943\end{array}$ & $\begin{array}{l}\text { Male adult } \ldots \ldots \ldots \\
\ldots \ldots \text { do } \ldots \ldots \ldots \ldots\end{array}$ & $\begin{array}{l}540 \\
510\end{array}$ & $\begin{array}{l}450 \\
385\end{array}$ & $\begin{array}{l}81 \\
75\end{array}$ & $\begin{array}{l}85 \\
78\end{array}$ & $\begin{array}{r}101.3 \\
93.0\end{array}$ & $\begin{array}{l}65.8 \\
57.2\end{array}$ & $\begin{array}{l}37.4 \\
36.0\end{array}$ \\
\hline Do & 124944 & Female adult. & 480 & 370 & 70 & 71 & 87.6 & 50.4 & 32.8 \\
\hline 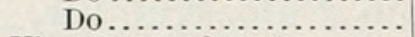 & 125023 & .....do do............ & 465 & 405 & 73 & 76 & 89.6 & 50.0 & 34.8 \\
\hline Viverra tangalunga. & 124945 & & 650 & 305 & 95 & 97 & 107.3 & 54.5 & 43.6 \\
\hline Do.. & 125025 & Male adult & 620 & 300 & 103 & 105 & 103.7 & 56.7 & 44.7 \\
\hline Arctogalidia minor. & a 124984 & Female adult..... & 440 & 435 & 68 & 74 & 81.5 & 46.7 & 31.8 \\
\hline
\end{tabular}

a Type.

TUPAIA INFLATA, new species.

1888. Tupaia javanica Jentink, Mus. d'Hist. Nat. Pays-Bas, XII, 1888, p. 117.

1890. Tupaia javanica Jentink, Notes from Leyden Museum, XXII, p. 152, March, 1890.

1905. Tupaia javinica Willink, Natuurkundig Tijdschrift Nederlandsch-Indië, LXV, p. 298.

Type.-Adult male, skin and skull, Cat. No. 124709, U.S.N.M., collected at Tanjong Rengsam, island of Banka, east of Sumatra, May 20, 1904, by Dr. W. L. Abbott. Original number, 3241.

Diagnostic characters.-A small member of the genus related to malaccana, javanica, and minor. It is larger than malaccana (hind foot 38 against 34 ) with a darker belly and obscured shoulder stripe. It is about the same size as javanica, but much lighter both above and below, and with longer tail. The skull is slightly larger than that of malaccana, decidedly shorter than that of javanica, and has the brain case more inflated than in either of them. In comparing inflata with minor in the British Museum, Mr. Miller noted that the skull of inflata is slightly greater in size, and has the brain case conspicuously deeper and more inflated than it is in minor.

Color.-Type: Cpper surface of head and body a fine grizzle of black and a color between russet and tawny olive, the russet being more conspicuous anteriorly and the tawny olive posteriorly. Sides of body, outer surfaces of legs and feet similar in color to the back, but the black of the hairs not so much in evidence. Cheeks and sides of neck almost pure light russet with a slight grizzling of black. Chin, throat, anterior part of chest, inner side of forelegs and posterior part of belly, a light dull ochraceous or ochraceous-buff, darkest in the throat. Middle of the underparts has a suffused patch 25 or $30 \mathrm{~mm}$. in width 
formed by an extension of the colors of the sides. Inner side of hind legs grayish. Hairs of the tail, blackish, ringed with a light tawny olive above and below with conspicuous rings of grayish which is the color of the base of the hairs below.

Color of the rest of the series: Upper parts as in the type. The majority of the specimens have the underparts more grayish and less ochraceous than has the type. In all there is a suffusion of the color of the sides over the middle of the belly. Two of the specimens, Cat. No. 124985, from Billiton, and Cat. No. 124909, from Banka, have the tails in a different pelage from the others, the base of the hairs underneath being tawny ochraceous and ringed above and laterally with a slight tint of the same color.

Skull and teeth.-The skull is distinctly smaller and with a shorter rostrum than that of Tupaia javanica and with more inflated brain case and bullæ. It is slightly larger than the skull of T. malaccana and with more inflated brain case and bullæ. The teeth of Tupaia inflata average a little larger than those of $T$. malaccana and a little smaller than those of $T$. javanica.

Measurements.-External measurements of type. ${ }^{a}$ Total length, 322 mm.; head and body, 150 (155, 139); tail vertebræ, 172 (130, 146); hind foot, $38(35,34)$.

Cranial measurements of the type.-Greatest length of skull, $39 \mathrm{~mm}$. (43.5, 37.5); condylo-basal length, 37 (40, 35); basal length, 34 (37, $31)$; palatal length, $20(22.5,18)$; zygomatic breadth, 22 (23, 21); least interorbital breadth, $13(13.5,12.5)$; breadth of brain case above roots of zygomata, $17.5(17.5,17)$; height of brain case, middle of basioccipital to top of vault of cranium, $13.5(12,12)$; breadth of palate between middle molars, $7.5(7.5,6.5)$; maxillary tooth row, exclusive of incisors (alveoli), 13 (14, 12.5); mandible, condyle to front of symphysis, $26(28,25)$; mandibular tooth row, exclusive of incisors (alveoli), 13 (14, 12.5).

Specimens examined.- Six skins and skulls, three from Billiton and three from Banka.

Remarks.-Tupaia inflata is apparently a well-marked form, easily distinguishable from T. jananica and $T$. malaccana. As noted above, Mr. Miller in comparing $T$. inflata with $T$. minor found them readily separable by cranial characters.

$a$ The figures in parentheses are those of an average specimen of $T$. javanica and T. malaccana, respectively. For measurements of the series see table page 603 . 
TUPAIA DISCOLOR, new species.

1905. Tupaia ferruginea WILlink, Natuurkundig Tijdschrift Nederlandsch-Indië, LXV, p. 298.

Type.-Adult female, skin and skull, Cat. No. 124703, U.S.N.M., collected at Tanjong Rengsam, island of Banka, east of Sumatra, May 24, 1904, by Dr. W. L. Abbott. Original number, 3262.

Diagnostic characters. - Similar to Tupaia ferruginea Raffles, but lower half of back distinctly grayish, belly tawny (as in T. chrysogaster Miller) instead of grayish. Shoulder stripe conspicuous, bright tawny instead of grayish as in ferruginea. Teeth smaller, bullæ and brain case more inflated than in ferruginea.

Color.-Type: Upper parts of head, neck, anterior half of back and outer sides of forelegs has the general effect of a deep, rich hazel finely grizzled with blackish. At the middle of the back this effect passes into a grizzle of raw sienna and black, extending over the posterior half of body and outer side of hind legs. Brightest portions of the underparts (middle of belly, axillæ, and bordering sides of neck) dull tawny ochraceous gradually lightening out elsewhere into dull ochraceous buff. The conspicuous shoulder stripe, ochraceous rufous. Upper surface of tail blackish, finely and sparingly grizzled with cream buff. On the under surface of tail a dirty cream-buff predominates except along the outer edges, where the colors are the same as - the upper surface. Feet blackish brown, sparingly grizzled with the light colors of the legs.

Skull and teeth.- Skull similar to that of Tupaia fermiginea, but slightly smaller, with smaller teeth, the crowns of first and second maxillary molars more nearly quadrate, bullæ distinctly larger, and brain case more inflated.

Measurements.-External and cranial measurements of the type: ${ }^{a}$ Total length, $395 \mathrm{~mm}$; head and body, 220; tail vertebræ, 175 (collector's measurements); hind foot, 49 (from dried skin); greatest length of skull, 495; basal length, 44; condylo-basal length, 47; palatal length, 27; upper length, 48; zygomatic breadth, 25.5; least interorbital breadth, 14; breadth of brain case above roots of zygomata, 19; breadth of palate between middle molars, 10.5; maxillary tooth row, exclusive of incisors (alveoli), 19; mandible condyle to front of symphysis, 34; mandibular tooth row, exclusive of incisors, 19.

Specimens examined.-Nine skins with skulls, one odd skull, and two in alcohol, collected at Tanjong Rengsam; two skins with skulls and one in alcohol from Klabat Bay.

Remarls. - The series of skins and skulls is very uniform. There are no noticeable individual variations; an immature individual has 
the same color pattern as the adults. Tupaia discolor is apparently a very distinct species though related to fermiginea, but differs sharply, as mentioned above. Mr. Gerrit S. Miller, jr., who compared specimens of it with forms in the British Museum, noted that externally it is much like hypochrysa, but upper parts distinctly more red anteriorly and more gray posteriorly, the two regions forming a noticeable contrast of which there is none in hypochrysa. Underparts much lighter than in hypochrysa, especially on posterior half of belly and inner surface of hind legs. In hypochrysa the inside of hind leg is so dark that it forms no noticeable contrast with the outer side, while in discolor the contrast is sharp and very conspicuous. The same differences are found in both species, but to a less degree in the front legs. Shoulder stripe practically absent in hypochrysa, noticeable though small in discolor. Tail as in hypochrysa, but not quite as long haired, and longitudinal lines on underside less distinct. Skull and teeth noticeably smaller than in hypochrysa.

External and cranial measurements of tree shrews from Banka and Billiton.



a Alcoholic.

$b$ Skin and skull.

c Type.

$d$ Skull only.

e Young.

\section{CYNOPTERUS BRACHYOTIS (Müller).}

Seven specimens from Banka and eighteen from Billiton. I can find no differences between these and specimens of Cynopterus brachyotis from Borneo, the type locality. (See table of measurements, page 604.) 
Measurements of Cynopterus brachyotis from Billiton, Banka, and Borneo.

\begin{tabular}{|c|c|c|c|c|c|c|c|c|c|c|c|c|}
\hline Name. & Locality. & $\begin{array}{c}\text { Num- } \\
\text { ber. }\end{array}$ & Sex. & 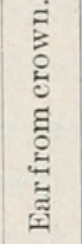 & ᄅ゙્ &  & 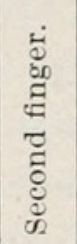 & 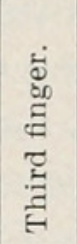 & 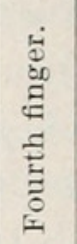 & 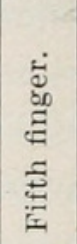 & $\frac{\mathscr{\Xi}}{\frac{0}{6}}$ & 官 \\
\hline 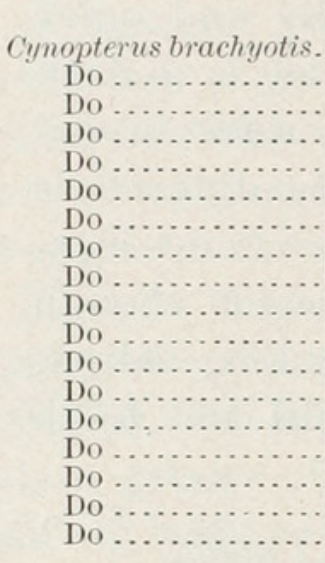 &  & $\begin{array}{l}124950 \\
124951 \\
124952 \\
124953 \\
124954 \\
124955 \\
124956 \\
124957 \\
124958 \\
124959 \\
124722 \\
124724 \\
142382 \\
142383 \\
142362 \\
142366 \\
142369 \\
142371\end{array}$ & 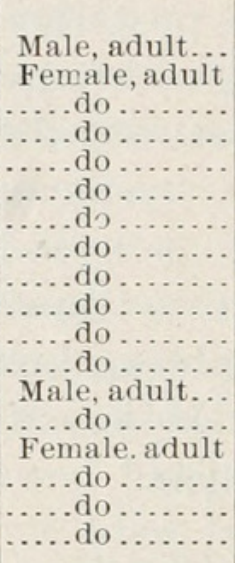 & $\begin{array}{l}m m . \\
14.0 \\
17.0 \\
15.0 \\
15.0 \\
14.0 \\
15.0 \\
15.0 \\
16.0 \\
14.0 \\
17.0 \\
15.0 \\
17.0 \\
13.0 \\
15.0 \\
17.0 \\
15.0 \\
14.5 \\
14.0\end{array}$ & $\begin{array}{l}m m . \\
7.5 \\
9.0 \\
6.0 \\
6.0 \\
8.0 \\
8.0 \\
6.5 \\
7.0 \\
7.0 \\
7.5 \\
8.5 \\
5.0 \\
6.5 \\
9.0 \\
9.0 \\
7.0 \\
7.0 \\
7.5\end{array}$ & $\begin{array}{r}m m \\
63 \\
63 \\
60 \\
61 \\
63 \\
62 \\
64 \\
62 \\
62 \\
60 \\
63 \\
66 \\
60 \\
60 \\
66 \\
62 \\
63 \\
64\end{array}$ & $\begin{array}{r}m m \\
41 \\
42 \\
38 \\
40 \\
42 \\
43 \\
43 \\
44 \\
41 \\
40 \\
45 \\
43 \\
40 \\
44 \\
43 \\
43 \\
41 \\
41\end{array}$ & $\begin{array}{r}m m . \\
93 \\
98 \\
92 \\
96 \\
92 \\
95 \\
100 \\
100 \\
92 \\
93 \\
97 \\
98 \\
91 \\
97 \\
104 \\
97 \\
96 \\
94\end{array}$ & $\begin{array}{r}m m . \\
80 \\
80 \\
76 \\
80 \\
79 \\
78 \\
81 \\
86 \\
81 \\
77 \\
78 \\
87 \\
79 \\
78 \\
88 \\
82 \\
84 \\
78\end{array}$ & $\begin{array}{r}m m . \\
80 \\
80 \\
77 \\
77 \\
80 \\
78 \\
83 \\
83 \\
77 \\
80 \\
81 \\
85 \\
76 \\
76 \\
85 \\
81 \\
82 \\
78\end{array}$ & $\begin{array}{r}m m . \\
26 \\
25 \\
24 \\
25 \\
24 \\
26 \\
26 \\
25 \\
23 \\
24 \\
24 \\
27 \\
25 \\
25 \\
27 \\
25 \\
26 \\
25\end{array}$ & $\begin{array}{c}m m . \\
14.0 \\
13.0 \\
13.0 \\
13.0 \\
13.0 \\
14.0 \\
14.0 \\
12.0 \\
13.0 \\
14.0 \\
13.0 \\
14.0 \\
13.0 \\
14.0 \\
16.0 \\
13.5 \\
16.0 \\
13.0\end{array}$ \\
\hline
\end{tabular}

\section{RHINOLOPHUS SOLITARIUS Andersen.}

1905. Rhinolophus solitarius Andersen, Ann. and Mag. Nat. Hist., 7th ser., XVI, August, 1905, p. 250.

One specimen of a Rhinolophus secured by Doctor Abbott at Tanjong Pamuja, Banka, has been made the type of this species by Dr. Knud Andersen. In his diagnosis it is said to be "allied to Rh. trifoliatus [found on. Borneo, Malay Peninsula, Java], but slightly smaller and with very short tail and tibia. Forearm $46.5 \mathrm{~mm}$."

No bat of this genus was collected by Doctor Abbott on Billiton. Jentink $^{a}$ records one specimen of Rhinolophus trifoliatus from that island.

\section{HIPPOSIDEROS GALERITUS (Cantor.)}

A large series of this bat in formalin was collected by Doctor Abbott on Banka. They have been kindly identified as this species by Dr. Knud Andersen, who has compared the alcoholics and skulls with the type of Ilipposideros galeritus and other species of the galeritus section of the genus. Dr. Andersen gives the following maximum and minimum measurements: 12 adult males: forearm, 50.3$48.3 \mathrm{~mm}$; metacarpal, third digit, 38-34.7; first phalanx, third digit, 17.5-15.2; second phalanx, third digit, 17.8-15; tail, 28-23; lower leg, 19.2-18; 7 adult females: forearm, 51.5-50 mm.; metacarpal, third digit, 39-35.2; first phalanx, third digit, 17-16; second phalanx, third digit, 17-16.7; tail, 29.5-26; lower leg, 19-18.2.

No bats of this genus were taken on the island of Billiton, and none are recorded from there by Jentink. 


\section{EMBALLONURA PENINSULARIS Miller.}

1890. Emballonura semicaudata Jentink, Notes Leyden Museum, XII, 1890, p. 154.

1905. Emballonura semicaudata WILLINK, Natuurkundig Tidjschrift NederlandschIndië, LXV, p. 284 (Billiton).

Two specimens from Tanjong Bedaan, Banka, and three from Tanjong Poetak, Billiton. Cat. Nos. 124746 male and 124747 female, U.S.N.M., Banka, measure, respectively: forearm, 44, 42; second finger, 36, 36; third finger, 65 , 66 ; fourth finger, 47, 46; fifth finger, 42, 45; tibia, 15.5, 16; foot, 7.4, 6.5; tail, 12, 11 . Cat. No. 124998, U.S.N.M., male, No. 124999 female, №. 125000 female, Billiton measure, respectively; forearm, 42, - ,44; second finger, 35, 36, 38; third finger, 60, 67, 67; fourth finger, 44, 46, 48; fifth finger, 40, 45, 46 ; tibia, $16.7,17.5,17.5$; foot, $8,7.6,7.5$; tail, 10, 11, 12 .

MYOTIS CARIMAT $Æ$ Miller.

Four specimens of a Myotis, none of them fully adult, taken on the small island of Mendanau, just west of Billiton show no appreciable differences from Myotis carimatæ Miller of the Karimata Islands off the west coast of Borneo.

\section{NYCTICEBUS BANCANUS Lyon.}

1905. Nycticebus tardigradus WiLlink, Natuurkundig Tijdschrift NederlandschIndië, LXV, p. 181.

1906. Nycticebus bancanus Lyon, Proc. U. S. Nat. Mus., XXXI p. 536.

A specimen of a slow lemur was secured by Doctor Abbott at Klabat Bay, Banka. It is related to, but distinct from the Bornean Nycticebus. For measurements of this and related species see table page 537 of this volume.

\section{TARSIUS TARSIER (Erxleben).}

1905. Tarsius spectrum WiLlink, Natuurkundig Tijdschrift Nederlandsch-Indië, XLV, p. 179 (Banka, Billiton).

One specimen, an adult female, was taken at Buding Bay, Billiton. The lower back, rump, and outer surface of fore and hind legs is generally similar to Ridgway's ochraceous-buff; general color of back of head and upper back an indefinite buffy gray or light brownish (can not be matched in Ridgway); face and an ill-defined band across shoulders, ochraceous or tawny-ochraceous. "Iris pale grayish brown, tail dull reddish brown, paler beneath at base; palmar and solar pads, very pale brownish fleshy."

Measurements.-Head and body, $133 \mathrm{~mm}$.; tail, 228; hind foot, 68; greatest length of skull, 37; basal length, 26.8; greatest width of skull, 33.5 ; interorbital constriction, 2.4; front of middle incisor to back outer angle of last upper molar, 16.5. 
It is not at all probable that this specimen is true Tarsius tarsier, but without more material and especially without examples from Java, which is probably the type locality, it is impossible to determine its status.

It is apparently very different from Tarsius bancanus Horsfield, ${ }^{a}$ which is distinct enough to constitute another genus if Horsfield's description and figures of the teeth represent a normal specimen. Doctor Abbott failed to secure any Tarsiers on Banka.

\section{MACACA PHÆURA (Miller).}

Macaens cynomolgus WiLLINk, Natuurkundig Tijdschrift Nederlandsch-Indië, XLV, p. 175 .

Two Macaques were shot on Banka and two on Billiton, which do not differ essentially from Macaca phæura Miller of Nias Island. They are a little darker in color than most of the Nias specimens, but one of the latter is almost an exact match for the Banka-Billiton skins. I can see no real differences in the skulls. The majority of the Nias specimens have slightly larger feet and weigh a little more than the Banka-Billiton ones, but these differences are well within the limits of individual variation. (See table of measurements of $M$. phæura, page 606.)

Measurements of Macaca phæura.

\begin{tabular}{|c|c|c|c|c|c|c|c|c|}
\hline Locality. & $\begin{array}{l}\text { Num- } \\
\text { ber. }\end{array}$ & Sex. & Age. & 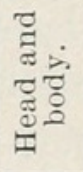 & $\stackrel{\widetilde{\sigma}}{\overparen{్}}$ & 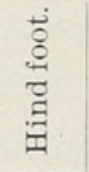 & 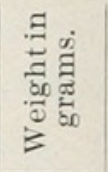 & 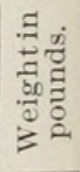 \\
\hline 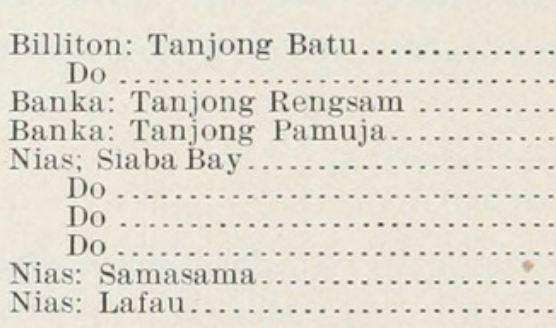 & $\begin{array}{r}124969 \\
124970 \\
124710 \\
124863 \\
121868 \\
121869 \\
\alpha 121870 \\
121871 \\
141371 \\
141372\end{array}$ & $\begin{array}{l}\text { Male } \ldots \\
\ldots \text { do } \ldots \\
\ldots \text { do } \ldots . \\
\ldots \text { do } \ldots \\
\ldots \text { do } \ldots \\
\text { Female. } \\
\text { Male } \ldots \\
\ldots \text { do } \ldots \\
\ldots \text { do } \ldots \\
\ldots \text { do } \ldots\end{array}$ & $\begin{array}{l}\text { Old adult... } \\
\text { Adult } \ldots \ldots . . \\
\text { Old adult... } \\
\ldots \ldots \text { do } \ldots . . . \\
\text { Adult } \ldots . . . \\
\ldots \ldots \text { do } \ldots . . . \\
\ldots \ldots \text { do } \ldots \ldots . \\
\text { Old adult... } \\
\ldots \ldots \text { do } \ldots . . . \\
\text { Adult } \ldots . . .\end{array}$ & $\begin{array}{r}m m . \\
485 \\
450 \\
442 \\
435 \\
430 \\
385 \\
460 \\
450 \\
490 \\
475\end{array}$ & $\begin{array}{r}m m \\
480 \\
445 \\
435 \\
520 \\
490 \\
400 \\
480 \\
500 \\
560 \\
515\end{array}$ & $\begin{array}{l}m m . \\
122 \\
113 \\
119 \\
122 \\
122 \\
110 \\
130 \\
128 \\
140 \\
138\end{array}$ & $\begin{array}{l}g m s \\
4,536 \\
4,423 \\
4,536 \\
5,330 \\
5,103 \\
2,948 \\
4,990 \\
4,876 \\
5,443 \\
5,897\end{array}$ & $\begin{array}{c}c b s . \\
10 \\
9 \\
10 \\
11 \\
11 \\
6 \\
11 \\
10 \\
12 \\
13\end{array}$ \\
\hline
\end{tabular}

a Type.

Measurements of Presbytis cristata.

\begin{tabular}{|c|c|c|c|c|c|c|c|c|}
\hline Locality. & $\begin{array}{c}\text { Num- } \\
\text { ber. }\end{array}$ & Sex. & Age. & 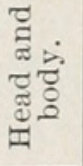 & Е్స్త్ర & $\underset{\stackrel{0}{0}}{\stackrel{0}{\Xi}}$ & 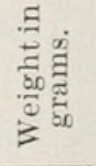 & 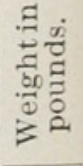 \\
\hline 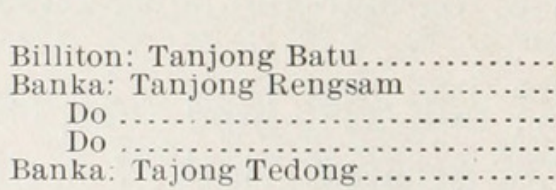 & $\begin{array}{l}124971 \\
124711 \\
124712 \\
124713 \\
124725\end{array}$ & $\begin{array}{l}\text { Female. } \\
\ldots \text { do } \ldots \\
\ldots \text { do } \ldots \\
\ldots \text {.... } \\
\text { Male } \ldots\end{array}$ & $\begin{array}{l}\text { Adult } \ldots \ldots \text {. } \\
\ldots \ldots \text { do } \ldots \ldots \text {. } \\
\ldots \ldots \text { do } \ldots \ldots \\
\ldots \ldots \text { do } \ldots \ldots \\
\ldots \ldots \text { do } \ldots \ldots\end{array}$ & $\begin{array}{r}m m . \\
470 \\
460 \\
495 \\
510 \\
545\end{array}$ & $\begin{array}{r}m m \\
655 \\
680 \\
645 \\
650 \\
735\end{array}$ & $\begin{array}{r}m m . \\
140 \\
135 \\
135 \\
142 \\
150\end{array}$ & $\begin{array}{l}g m s . \\
6,350 \\
5,783 \\
6,010 \\
6,464 \\
8,164\end{array}$ & $\begin{array}{c}l b s . \\
14 \\
12 \frac{1}{4} \\
13 \frac{1}{4} \\
14 \frac{1}{4} \\
18\end{array}$ \\
\hline
\end{tabular}

a Zoological Researches in Java, 1824, description, plate of entire animal and figures of teeth "G" on a second plate. (Pages and plates are not numbered.) 


\section{PRESBYTIS CRISTATA (Raffles).}

1905. Semnopithecus pruinosus WiLlink, Natuurkundig Tijdschrift NederlandschIndië, XLV, p. 170.

Four specimens from Banka and one from Billiton. They differ in no essential respects from specimens from Sumatra. The light colored subapical rings in three of the five skins are less conspicuous than they are in Sumatran examples. (For table of measurements see page 606.)

\section{NOTES BY DOCTOR ABBOTT ON HIS COLLECTING STATIONS.}

(See Map, page 577.)

BANKA.

Tanjong Rengsam.-May 20 to 28, 1904. The coast at Tanjong Rengsam is rather flat, with low hills in the interior. The neighborhood is mostly covered with secondary jungle and patches of lalang grass. There is one piece of heavy for est on the seashore, covering about 1 square mile, which has been preserved by the Bankanese for the sake of the timber. Some small plantations of cocoanuts are on the shore. Only four or five families live here. At the mouth of the Jering River, 3 miles away, is the large kampong [village] of Nyor. The natives are all Bankanese.

Tanjong Tedong.-May 31 to June 4, 1904. At Tanjong Tedong is a bluff extending along the seashore. Most of the neighborhood is covered with secondary jungle, the swampy land only being covered with heavy forest. The small kampong of Tanjong Tedong lies on the shores of the strait opposite Pulo Nangka Besar [not shown on the map]. The inhabitants are Bankanese.

Tanjong Bedaan and Parmissan.-June 6 to 15, 1904. Tanjong Bedaan (Bedaan on the charts) is a rocky point, the neighborhood mostly covered with secondary jungle, much of it old. A good deal of tin mining is carried on in the neighborhood. The large kampong: (100 houses) of Parmassan (or Parmissan) lies about a mile inland, in a northeast direction. Bukit Parmissan is a range of hills, 5 or 6 miles long, lying 2 or 3 miles back from the sea. Its highest point is 1,600 feet, and is the second highest peak in Banka. The lower slopes of Parmissan Hill are covered with small jungle or dense scrub, at least the parts nearest the kampong, but the upper parts are covered with high open forest. Kampong Parmissan is inhabited by Sumatran Malays. Most of the parits, or tin diggings, are situated on the seashore, and a number of Chinamen live there.

Tanjong Pamuja.-June 17 to 21, 1904. Doctor Abbott made no special notes on this place. His account of the north shore of Banka is under Klabat Bay, below. 
Klabat Bay.- June 22 to July 3, 1904. The north coast of Banka is fronted by broad beaches of white sand, separated by rocky points. The anchorages are not very good. It is necessary to anchor threequarters of a mile from shore, as the holding ground is not very good in the hard sand. 'The coast line is thinly inhabited, and covered with forest, with a fringe a casuarinas behind the sand tracts. There are a few parits (tin diggings) a few miles inland, and on the coast during the fine season a number of Bankanese and Chinese live in temporary huts or shelters, fishing for the supply of the tin miners.

The west coast of Klabat Bay near the entrance is covered with heavy forest intersected with many paths made by woodcutters. It is mostly rolling country and dry at all seasons, a good place for collecting, but the coral reefs project so far from shore that it was a very inconvenient place for me to work. I had to anchor $1 \frac{1}{2}$ miles from shore.

The east side of Klabat Bay is inhabited and for the most part swampy or covered with secondary jungle. Many tin diggings occur not far inland. Around the head of Klabat Bay are many villages and tin diggings.

Tanjong Mengkudu.-July 3 to 4, 1904. Doctor Abbott made no notes on this locality. It is opposite the small Pulo Mengkudu on the map.

\section{MENDANAU.}

Pulo Mendanau.-July 14 to 15, 1904. Pulo Mendanau is about 8 by 7 geographical miles and lies west of Billiton, separated by a strait $3 \frac{1}{2}$ miles wide and 10 fathoms deep. Much of the surface is low and swampy. The highest hills are about 600 feet high. There is very little virgin forest left, the jungle being mostly scrubby secondary, and there are large tracts of lalang. Besides the animals obtained, a form of Tragulus kanchil is said to exist. It is not found on Billiton. No napu exist and no pigs.

\section{BILLITON.}

Billiton is about 43 miles square and contains about 1,600 square miles. The surface is mostly low, rolling hills, presenting a flat appearance from the sea, with isolated higher hills. The highest points are Tajem Laki and Tajem Bini, each about 1,770 feet high. The island has been largely worked for tin during the past fifty-two years, but the production of tin is now diminishing.

There is no heavy forest left upon the seacoast, but there is said to be a good deal left in the interior, especially in the south and west. I only found one small tract of virgin forest, on and around Bukit Mengúru, west of Buding Bay. The rest of the island is covered with secondary jungle and tracts of lalang (coarse grass). 
There are about 9,000 Chinese miners. The native inhabitants are Malays and a "wild tribe" called "Orang Sikka," who live exclusively in their boats and do not cultivate the land, living on the produce of the reefs and sea.

Besides the animals obtained, pigs were common, in some places evidently very abundant. I had a glimpse of only one. Tenggéling: (Manis) is said to exist. The Tupai blang (Sciurus "prevostii") is said to occur, but is rare. I did not see it.

\section{LIST OF MAMMALS RECORDED FROM THE. ISLANDS OF BANKA, BILLITON, AND MENDANAU, WITH FIELD NOTES ON THOSE COLLECTED AND OBSERVED BY DOCTOR ABBOTT.}

\section{BANKA.}

Manis javanica.-Jentink, Mus. d'Hist. Nat. Pays-Bas, XII, Cat. Syst. Mammifères, p. 216. Manisjavanica-Willink, Natuurkundig Tijdschrift Nederlandsch-Indië, LXV, 1905, p. 269. Not taken by Doctor Abbott, but "said to be common."

Tragulus bancanus, p. 576 .

Tragulus luteicollis, p. 579.

Muntiacus bancanus, p. 582.- "Native name Kijang."

Rusa brookei.- "Besides the animals obtained, I saw Cervus equinus, tracks only; saw some horns in possession of the natives, all very small. The Bankanese said Rusa and Kijang were numerous on Tanjong Penyusuh, but I did not go there, as it was not possible to anchor near shore." Recorded by Jentink ${ }^{a}$ and by Willink ${ }^{b}$ as Russa equina.

Sus oi, p. 585._-"The only (four) pigs I got were all immature and are, I think, of one species.'”

Sus vittatus WiLlink, Natuurkundig Tijdschrift Nederlandsch-Indië, XLV, p. 183.

Ratufa polia bancana, p. 587.

Sciurus bangkanus, p. 589 .

Sciurus tedongus, p. 591.

Sciuropterus aurantiacus.-Jentink, Mus. d'Hist. Nat. Pays-Bas, XII, Cat. Syst. Mammifères, 1888 , p. 6.

Sciuropterus sagitta.-Jentink, Mus. d'Hist. Nat. Pays-Bas, XII, Cat. Syst. Mammitères, 1888, p. 6. Willink, Natuurkundig Tijdschrift Nederlandsch-Indië, LXV, 1905 , p. 232.

Petaurista._- "Said to occur, but I did not meet with it." Not recorded by Jentink or Willink.

Nannosciurus bancanus, p. 594.-_"The little Nannosciurus occurs locally and is then common."

Mus firmus, p. 594.

Mus cremoriventer, p. 595.

Mus asper, p. 595.

Mus clabatus, p. 596._-"Rats were scarce on Banka."

Viverra tangalunga.-Jentink, Mus. d'Hist. Nat. Pays-Bas, IX, Cat. Osteol. Mammifères, 1887, p. 90. Willink, Natuurkundig Tijdschrift Nederlandsch-Indië, LXV, 1905, p. 210. Not taken by Doctor Abbott, but in his notes it is said to occur.

Viverricula malaccensis Willink. Natuurkundig Tijdschrift. Nederlandsch-Indië, LXV, 1905, p. 211.

$a$ Mus. d'Hist. Nat. Pays-Bas, IX, Cat. Osteol. Mammifères, 1887, p. 149.

${ }^{b}$ Natuurkundig Tijdschrift Nederlandsch-Indië, XLV, 1905, p. 190.

Proc. N. M. vol. $\mathrm{xxxi-06-40}$ 
Paradoxurus hermaphroditus, p. 597.

Linsang linsang.-Prionodon gracilis, Jentink, Mus. d'Hist. Nat. Pays-Bas, IX, Cat. Osteol. Mammifères, 1887, p. 92 . Lingsanga gracilis Willink, Natuurkundig Tijdschrift Nederlandsch-Indië, LXV, 1905, p. 212.

Arctictis binturong.-Jentink, Mus. d'Hist. Nat. Pays-Bas, IX, Cat. Osteol. Mammifères, 1887, p. 96 . Willink, Natuurkundig Tijdschrift Nederlandsch-Indië, LXV, 1905, p. 216.

Herpestes javanicus Willink, Natuurkundig Tijdschrift Nederlandsch-Indië, LXV, 1905 , p. 218.

Barangia sumatrana.-Jentink, Mus. d'Hist. Nat. Pays-Bas, IX, Cat. Osteol. Mammifères, 1887, p. 115. Doctor Abbott mentions an otter as occurring on Banka, but saw none.

Ursus malayanus.-Jentink, Mus. d'Hist. Nat. Pays-Bas, IX, Cat. Osteol. Mammifères, 1887, p. 119 . Doctor Abbott mentions the bear as occurring, but not meeting with it.

Felis._-"There is a wild cat, but I did not meet with it."

Ptilocercuslowii.-Jentink, Mus. d'Hist. Nat. Pays-Bas, XII, Cat. Syst. Mammifères, 1888, p. 118. Willink, Natuurkundig Tijdschrift Nederlandsch-Indië, LXV, 1905, p. 300 .

Tupaia inflata, p. 600 .

Tupaia discolor, p. 602.

Tupaia tana Willink, Natuurkundig Tijdschrift Nederlandsch-Indië, LXV, 1905, p. 296.

?Crocidura vosmxri.-Jentink, Mus. d'Hist. Nat. Pays-Bas, XII, Cat. Syst. Mammifères, 1888 , p. 34.

Cynocephalus volans._Galeopithecus volans, Jentink, Mus. d'Hist. Nat. Pays-Bas, IX, Cat. Osteol. Mammifères, 1887, p. 69. Willink, Natuurkundig Tijdschrift Nederlandsch-Indië, LXV, 1905, p. 270. "Did not get the Kubang (Galeopithecus), but this animal exists there."

Emballonura peninsularis, p. 605.

Rhinolophus solitarius, p. 604.- "Hanging beneath a palm leaf in heavy forest."

Hipposideros galeritus, p. 604._" "These bats were roosting in small caves or rather overhanging rocks upon Tanjong Pamuja. Beneath one rock was a dense mass roosting, and I obtained 63 individuals with two shots of the .32-caliber auxiliary barrel besides many more that dropped into crevices beneath and were lost."

Pteropus edulis.-Jentink, Mus. d'Hist. Nat. Pays-Bas, XII, Cat. Syst. Mammifères, 1888, p. 145. Willink, Natuurkundig Tijdschrift Nederlandsch-Indië, LXV, 1905, p. 273.

Cynopterus brachyotis, p. 603.- "Specimens shot hanging upon a casuarina tree on seashore."

Vespertilio brachypterus Willink, Natuurkundig Tijdschrift Nederlandsch-Indië, LXV, 1905, p. 288.

Nycticebus bancanus, p. 605 .

Tarsius bancanus.-Horsfield, Zool. Researches in Java, 1824, T. Spectrum, Schlegel, Mus. d'Hist. Nat. Pays-Bas, VII, Simịæ, 1876, pp. 179, 333. Doctor Abbott remarks: "I failed to get the Tarsier, although all the natives knew it, which they called 'Méntäling.' They had not all seen it, and either the animal is scarce or more probably rarely seen, owing to its nocturnal habits. They said if I remained some time in Muntok (the capital) I would be sure to get them, as there was a regular demand there for them by the doctors (?) and they were brought there for sale."

Macaca phæura, p. 606.

Macaca nemestrina.-Macacus nemestrinus Schlegel, Mus. d'Hist. Nat. Pays-Bas, VII, Simiæ, 1876, p. 111. No specimens listed. ${ }^{a}$ Willink, Natuurkundig Tijdschrift a"Ce singe habite les îles de Borneo, de Sumatra, et de Bangka." 
Nederlandsch-Indië, XLV, p. 176. "I saw only one Macaca nemestrina, a big male, which I fired at but did not get. I saw a few tame ones in the native kampongs, apparently like the Broh of Sumatra.' -W. L. A.

Presbytis cristata, p. 607.

Presbytis obscura.-Semnopithecus obscurus, Schlegel, Mus. d'Hist. Nat. Pays-Bas, VII, Simiæ, 1876, p. 49. No specimens listed. ${ }^{a}$ Willink, Natuurkundig Tijdschrift Nederlandsch-Indië, XLV, p. 168.

\section{MENDANAU.}

Tragulus "kanchil." - "Heard that a Kanchil occurs on the island."

Sciurus mendanauus, p. 589._- A local race of Sciurus prevostii was common; specimens were shot at Kampong Petaling.'

Myotis carimatæ, p. 605. - "These bats were flying over a mangrove creek, generally skimming close to the surface of the water; flight slow."

\section{BILLITON.}

Manis.-Manis javanica.-Willink, Natuurkundig Tijdschrift Nederlandsch-Indië, LXV, 1905, p. 269. "Tenggeling (Manis) is said to exist." No specimens taken.

Tragulus billitonus, p. 578._- A small napu is common; there is no kanchil or plandok." Jentink $b$ doubtfully recorded Tragulus kanchil from Billiton, thinking that kidang had the same meaning as kanchil among the natives; but kidang or kijang refers to the Muntiacus.

Muntiacus bancanus, p. 582._-"The Kijang was common, but I did not see it. I frequently heard them barking." Doctor Abbott obtained from the natives a pair of antlers and the frontlet.

Rusa brookei, p. 584.- "A small Rusa is common; I only shot one female."

Sus sp.-Doctor Abbott failed to obtain any pigs, but remarks: "They were common, in some places evidently very abundant; I only had a glimpse of one." No pigs are recorded by Jentink or Willink.

Ratufa polia, p. 585.- “"There were plenty of Ratufa at Bukit Mengúru, about $1 \frac{1}{2}$ miles west of Buding Bay. Local name Jiláling."

Sciurus prevostii.-Jentink, Notes Leyden Museum, XIII, 1891, p. 209; thought to be introduced. Willink, Natuurkundig Tijdschrift Nederlandsch-Indië, LXV, p. 240. Doctor Abbott remarks: "The Tupai blang (Sciurus prevostii) is said to occur, but it is rare. I did not see it. An old Malay said they occurred, but were rare, in the heavy forests of the interior of the island."

Sciurus billitonus, p. 592.

Sciuropterus vordermanni, p. 593._-"Local name Kăpó̄a."

Nannosciurus. - "I did not meet with Nannosciurus, although I occasionally heard its shrill whistle. The natives all knew it." Nannosciurus melanotis Willink, Natuurkundig Tijdschrift Nederlandsch-Indië, LXV, 1905, p. 249.

Mus cremoriventer, p. 595._-"Rats were scarce on Billiton."

Mus neglectus, p. 595.

Mus asper, p. 595.

Viverra tangalunga, p. 597._-"Trapped by natives."

Paradoxurus canescens, p. 597.-_"Trapped by natives."

Arctogalidia minor, p. 599._- "Local name for Musang is Gắling. This animal was one of a pair passing through the tree tops one evening. They were going to feed on a wild fruit tree, where I afterwards shot this one. As this genus keeps in the tree tops, it can not be trapped as Viverra and Paradoxurus are."

a"'Bleeker, enfin, m'assure avoir reçu ce singe de l'île de Bangka."

$b$ Notes Leyden Museum, XIII, 1891, p. 209. 
Tupaia inflata, p. 600 .

Cynocephalus volans - Galeopithecus volans Willink.-Natuurkundig Tijdschrift Nederlandsch-Indië, LXV, 1905, p. 270.

Pteropus edulis Willink, Natuurkundig Tijdschrift Nederlandsch-Indië, LXV, 1905, p. 273.

Cynopterus brachyotis, p. 603.

Rhinolophus trifoliatus.-Jentink, Notes Leyden Museum, XIII, 1891, p. 209.

Willink, Natuurkundig Tijdschrift Nederlandsch-Indië, LXV, 1905, p. 281.

Emballonura peninsularis, p. 605.- "These bats were in a small cave formed by fallen rocks on the shore."

Myotis muricola.-Vespertilio muricola, Jentink, Notes Leyden Museum, XIII, 1891, p. 209. Myotis muricola Willink, Natuurkundig Tijdschrift Nederlandsch-Indië, LXV, 1905, p. 293.

Pipistrellus vordermanni.--Vesperugo vordermanni, Jentink, Notes Leyden Museum, XIII, 1891, p. 209. Vespertilio vordermanni, Willink, Natuurkundig Tijdschrift Nederlandsch-Indië, LXV, 1905, p. 290.

Tarsius tarsier, p. 605.- "The Tarsius is probably common enough, but is rarely taken except when tree felling is in progress. The Nycticebus seems to be absent." Macaca phaeura, p. 606.

Presbytis cristata, p. 607. 


\section{$2 \mathrm{BHL}$ Biodiversity Heritage Library}

Lyon, Marcus Ward. 1906. "Mammals of Banka, Mendanau, and Billiton Islands, between Sumatra and Borneo." Proceedings of the United States National Museum 31(1498), 575-612.

https://doi.org/10.5479/si.00963801.31-1498.575.

View This Item Online: https://www.biodiversitylibrary.org/item/32804

DOI: https://doi.org/10.5479/si.00963801.31-1498.575

Permalink: https://www.biodiversitylibrary.org/partpdf/2097

\section{Holding Institution}

Smithsonian Libraries

\section{Sponsored by}

Smithsonian

\section{Copyright \& Reuse}

Copyright Status: NOT_IN_COPYRIGHT

This document was created from content at the Biodiversity Heritage Library, the world's largest open access digital library for biodiversity literature and archives. Visit BHL at https://www.biodiversitylibrary.org. 